\title{
Review of Constituents and Biological Activities of Triterpene Saponins from Glycyrrhizae Radix et Rhizoma and Its Solubilization Characteristics
}

\author{
Feifei $\mathrm{Li}^{1,2}{ }^{1}$, Bin Liu ${ }^{3}$, Tong $\mathrm{Li}^{1}{ }^{1}$, Qianwen $\mathrm{Wu}^{1}{ }^{1}$, Zhiyong $\mathrm{Xu}{ }^{4}$, Yuhao Gu ${ }^{1}$, Wen $\mathrm{Li}^{1}$, \\ Penglong Wang ${ }^{1}$, Tao Ma ${ }^{1}$ 递 and Haimin Lei ${ }^{1,2, *}$ \\ 1 School of Chinese Pharmacy, Beijing University of Chinese Medicine, Beijing 100102, China; \\ lifeifei902@163.com (F.L.); 1t1755258545@163.com (T.L.); winifredG@163.com (Q.W.); \\ gu2452260684@163.com (Y.G.); lw19991103@163.com (W.L.); wangpenglong@bucm.edu.cn (P.W.); \\ mosesmatao@163.com (T.M.) \\ 2 Institute of Regulatory Science for Traditional Chinese Medicine, Beijing University of Chinese Medicine, \\ Beijing 100102, China \\ 3 COFCO Nutrition and Health Research Institute, Beijing 102209, China; liubin11@cofco.com \\ 4 Key Laboratory of Computational Chemistry-Based Natural Antitumor Drug Research \& Development, \\ School of Traditional Chinese Materia Medica, Shenyang Pharmaceutical University, Shenyang 110016, \\ China;XZY9525@163.com \\ * Correspondence: leihm@bucm.edu.cn; Tel.: +86-010-5391-2106
}

Received: 25 July 2020; Accepted: 25 August 2020; Published: 27 August 2020

\begin{abstract}
Glycyrrhizae Radix et Rhizoma is regarded as one of the most popular and commonly used herbal medicines and has been used in traditional Chinese medicine (TCM) prescriptions for over 2000 years. Pentacyclic triterpene saponins are common secondary metabolites in these plants, which are synthesized via the isoprenoid pathway to produce a hydrophobic triterpenoid aglycone containing a hydrophilic sugar chain. This paper systematically summarizes the chemical structures of triterpene saponins in Glycyrrhizae Radix et Rhizoma and reviews and updates their main biological activities studies. Furthermore, the solubilization characteristics, influences, and mechanisms of Glycyrrhizae Radix et Rhizoma are elaborated. Solubilization of the triterpene saponins from Glycyrrhizae Radix et Rhizoma occurs because they contain the nonpolar sapogenin and water-soluble sidechain. The possible factors affecting the solubilization of Glycyrrhizae Radix et Rhizoma are mainly other crude drugs and the $\mathrm{pH}$ of the decoction. Triterpene saponins represented by glycyrrhizin from Glycyrrhizae Radix et Rhizoma characteristically form micelles due to amphiphilicity, which makes solubilization possible. This overview provides guidance regarding a better understanding of Glycyrrhizae Radix et Rhizoma and its TCM compatibility, alongside a theoretical basis for the further development and utilization of Glycyrrhizae Radix et Rhizoma.
\end{abstract}

Keywords: Glycyrrhizae Radix et Rhizoma; triterpene saponins; glycyrrhizin; biological activities; solubilization

\section{Introduction}

The Glycyrrhiza genus belongs to the Fabaceae family, comprising approximately 20 species primarily distributed across Asia, Europe, North America, and South America, with eight distributed throughout China [1]. Glycyrrhizae Radix et Rhizoma, also named glycyrrhiza or "Gan-Cao" in China and licorice or liquorice in Europe, is the dry root and rhizome of three official Glycyrrhiza species, namely, Glycyrrhiza uralensis Fisch, Glycyrrhiza glabra L., and Glycyrrhiza inflata Batal [2,3]. It is extensively used in traditional Chinese medicine (TCM) to treat hepatitis, influenza, cough, and gastric 
ulcers $[4,5]$. Glycyrrhiza is also of significant economic value, and its extract has been used in cosmetics, food ingredients, tobacco flavors, and functional foods [5-9].

In recent decades, extensive research has been conducted regarding the bioactive constituents, biosynthesis, pharmacological mechanisms, and clinical applications, in glycyrrhiza, among other aspects [5,10-13]. The major bioactive secondary metabolites of glycyrrhiza include triterpene saponins, various types of flavonoids, coumarins, polysaccharides, and other phenolics $[10,14]$. Unfortunately, no systematic review has been conducted as yet regarding the chemical structure, origin, and corresponding references of triterpenoid saponins. Even the number of triterpenoid saponins in some references is not up-to-date. Another aspect of concern is that the solubilization characteristics of glycyrrhiza also received increasing attention in recent years due to the possibility of triterpene saponins from glycyrrhiza increasing the solubility of coexisting bioactive constituents in herbal extracts [15]. Few reviews currently exist regarding this subject.

In this review, SciFinder, PubMed, Web of Science, China Journal Net, and relevant English and Chinese literature were used as information sources by the inclusion of the primary search terms "Glycyrrhizae Radix", "glycyrrhiza", "Gan-Cao", "liquorice", "licorice", "triterpene saponins", "constituent", "glycyrrhizin", "glycyrrhizic acid", "activities", "solubilization", and their combinations, mainly from 1984 to 2020 . We systematically summarize the chemical structures, origins, and solubilization characteristics of triterpene saponins in glycyrrhiza and mainly focus on their chemical structures and characterization as natural surfactants. In addition, their biological activities are also reviewed and updated.

\section{Triterpene Saponins and Their Bioactivities}

\subsection{Triterpene Saponins}

The investigations of the chemical constituents of glycyrrhiza led to the isolation of 77 triterpene saponins. Triterpenoid saponins are major components of glycyrrhiza, containing one or more sugar moieties attached to oleanane-type pentacyclic triterpenoid aglycones. All of the triterpenoid saponins (Figures 1-3) in glycyrrhiza are summarized in Table 1. There were 50 oleanane-type pentacyclic triterpene saponins obtained from G. uralensis (Figure 1), 38 from G. glabra (Figure 2), and only 13 from G. inflate (Figure 3).

Table 1. Information on triterpene saponins in glycyrrhiza.

\begin{tabular}{|c|c|c|c|}
\hline No. & Compound & Origin & References \\
\hline 1 & $\begin{array}{c}\text { glycyrrhizin (glycyrrhizic acid, } \\
\text { uralsaponin A or } \\
18 \beta \text {-glycyrrhizic acid) }\end{array}$ & $a, b, c$ & [16-20] \\
\hline 2 & uralsaponin B & $a, b$ & {$[16,21]$} \\
\hline 3 & licorice-saponin A3 & $\mathrm{a}, \mathrm{c}$ & {$[20,22]$} \\
\hline 4 & licorice-saponin B2 & $a, b$ & {$[22,23]$} \\
\hline 5 & licorice-saponin C2 & $a, b$ & {$[22,23]$} \\
\hline 6 & licorice-saponin D3 & $\mathrm{a}$ & [22] \\
\hline 7 & licorice-saponin E2 & $\mathrm{a}, \mathrm{c}$ & {$[20,22]$} \\
\hline 8 & licorice-saponin F3 & $\mathrm{a}$ & [24] \\
\hline 9 & licorice-saponin G2 & $a, b, c$ & {$[20,23,24]$} \\
\hline 10 & licorice-saponin $\mathrm{H} 2$ & $a, b$ & {$[23,24]$} \\
\hline 11 & licorice-saponin J2 & $a, b$ & {$[23,24]$} \\
\hline 12 & licorice-saponin K2 & $a, b$ & {$[21,24]$} \\
\hline 13 & licorice-saponin L3 & $\mathrm{a}$ & [25] \\
\hline 14 & $18 \alpha$-glycyrrhizic acid & $a, b$ & [17] \\
\hline 15 & apioglycyrrhizin & $b, c$ & {$[23,26]$} \\
\hline 16 & araboglycyrrhizin & $a, b, c$ & {$[23,26,27]$} \\
\hline 17 & $22 \beta$-acetoxylglycyrrhizin & $\mathrm{a}, \mathrm{c}$ & {$[20,28]$} \\
\hline
\end{tabular}


Table 1. Cont.

\begin{tabular}{|c|c|c|c|}
\hline No. & Compound & Origin & References \\
\hline 18 & $\begin{array}{l}3 \beta-O-[\beta-D-g l u c u r o n o p y r a n o s y l- \\
(1 \rightarrow 2)-\beta \text {-D-glucuronopyranosyl] } \\
\text {-glycyrretol }\end{array}$ & a & {$[28]$} \\
\hline 19 & $\begin{array}{c}3 \beta-O-[\beta \text {-D-glucuronopyranosyl- } \\
(1 \rightarrow 2)-\beta \text {-D-glucuronopyranosyl]- } \\
\text { olean-9,12-diene-30-oic acid }\end{array}$ & a & [28] \\
\hline 20 & uralsaponin C & a & [29] \\
\hline 21 & uralsaponin D & $\mathrm{a}, \mathrm{c}$ & {$[20,29]$} \\
\hline 22 & uralsaponin $\mathrm{E}$ & $\mathrm{a}$ & [29] \\
\hline 23 & uralsaponin F & a & [29] \\
\hline 24 & $\begin{array}{c}\text { 3-O-[ } \beta \text {-D-glucuronopyranosyl- } \\
(1 \rightarrow 2)-\beta \text {-D-galactopyranosyl] } \\
\text { glycyrrhetic acid }\end{array}$ & a & {$[30]$} \\
\hline 25 & $\begin{array}{l}\text { licorice-saponin M3 } \\
\text { (uralsaponin T) }\end{array}$ & $a, b$ & {$[27,31]$} \\
\hline 26 & licorice-saponin N4 & $a, b$ & {$[31,32]$} \\
\hline 27 & licorice-saponin $\mathrm{O} 4$ & $\mathrm{~b}$ & [31] \\
\hline 28 & uralsaponin M & a & {$[27]$} \\
\hline 29 & uralsaponin $\mathrm{N}$ & a & [27] \\
\hline 30 & uralsaponin $\mathrm{O}$ & a & [27] \\
\hline 31 & uralsaponin $\mathrm{P}$ & a & [27] \\
\hline 32 & uralsaponin Q & a & [27] \\
\hline 33 & uralsaponin $\widehat{R}$ & a & [27] \\
\hline 34 & uralsaponin S & a & [27] \\
\hline 35 & uralsaponin $\mathrm{U}$ & a & {$[27]$} \\
\hline 36 & uralsaponin $\mathrm{V}$ & $a, b$ & {$[21,27]$} \\
\hline 37 & uralsaponin $\mathrm{W}$ & a & {$[27]$} \\
\hline 38 & uralsaponin X & a & {$[27]$} \\
\hline 39 & uralsaponin $\mathrm{Y}$ & $\mathrm{a}$ & {$[27]$} \\
\hline 40 & $22 \beta$-acetoxyl-glycyrrhaldehyde & $\mathrm{a}, \mathrm{c}$ & {$[20,33]$} \\
\hline 41 & $\begin{array}{l}\text { 3-O- } \beta \text {-D-glucuronopyranosyl- } \\
\text { glycyrrhetinic acid }\end{array}$ & $a, b$ & {$[21,27]$} \\
\hline 42 & $\begin{array}{l}\text { 3-O-[ } \beta \text {-D-(6-methyl)glucuro-nopyranosyl } \\
(1 \rightarrow 2) \text {-D-glucurono-pyranosyl]- } \\
\text { 24-hydroxyglabrolide }\end{array}$ & a & {$[34]$} \\
\hline 43 & licorice-saponin P2 & c & [20] \\
\hline 44 & licorice-saponin Q2 & $c$ & {$[20]$} \\
\hline 45 & macedonoside $\widehat{A}$ & $b, c$ & {$[20,21]$} \\
\hline 46 & 24-hydroxy-licorice-saponin E2 & c & [20] \\
\hline 47 & macedonoside $\mathrm{E}$ & a & [35] \\
\hline 48 & $22 \beta$-acetyl-uralsaponin C & a & [35] \\
\hline 49 & licorice saponin M1 & $b$ & [21] \\
\hline 50 & licorice saponin M2 & $b$ & [21] \\
\hline 51 & licorice saponin M3 & $\mathrm{b}$ & [21] \\
\hline 52 & licorice saponin M4 & $\mathrm{b}$ & [21] \\
\hline 53 & 30-hydroxyglycyrrhizin & $\mathrm{b}$ & [23] \\
\hline 54 & glycyrrhizin-20-methanoate & $b$ & [23] \\
\hline 55 & 24-hydroxyglucoglycyrrhizin & $b$ & [23] \\
\hline 56 & rhaoglycyrrhizin & $b$ & [23] \\
\hline 57 & 11-deoxorhaoglycyrrhizin & $\mathrm{b}$ & [23] \\
\hline 58 & rhaoglucoglycyrrhizin & $\mathrm{b}$ & [23] \\
\hline 59 & rhaogalactoglycyrrhizin & $\mathrm{b}$ & [23] \\
\hline 60 & 11-deoxo-20 $\alpha$-glycyrrhizin & $b$ & [23] \\
\hline 61 & $20 \alpha$-galacturonoylglycyrrhizin & $b$ & [23] \\
\hline 62 & $20 \alpha$-rhaoglycyrrhizin & $\mathrm{b}$ & [23] \\
\hline 63 & glyuralsaponin A & a & [32] \\
\hline 64 & glyuralsaponin B & a & [32] \\
\hline 65 & glyuralsaponin C & a & [32] \\
\hline
\end{tabular}


Table 1. Cont

\begin{tabular}{cccc}
\hline No. & Compound & Origin & References \\
\hline $\mathbf{6 6}$ & glyuralsaponin D & $\mathrm{a}$ & {$[32]$} \\
$\mathbf{6 7}$ & glyuralsaponin E & $\mathrm{a}$ & {$[32]$} \\
$\mathbf{6 8}$ & glyuralsaponin F & $\mathrm{a}$ & {$[32]$} \\
$\mathbf{6 9}$ & glyuralsaponin G & $\mathrm{a}$ & {$[32]$} \\
$\mathbf{7 0}$ & glyuralsaponin H & $\mathrm{a}$ & {$[32]$} \\
$\mathbf{7 1}$ & glabasaponin A & $\mathrm{b}$ & {$[36]$} \\
$\mathbf{7 2}$ & glabasaponin B & $\mathrm{b}$ & {$[36]$} \\
$\mathbf{7 3}$ & glabasaponin C & $\mathrm{b}$ & {$[36]$} \\
$\mathbf{7 4}$ & glabasaponin D & $\mathrm{b}$ & {$[36]$} \\
$\mathbf{7 5}$ & glabasaponin E & $\mathrm{b}$ & {$[36]$} \\
$\mathbf{7 6}$ & glabasaponin F & $\mathrm{b}$ & {$[36]$} \\
$\mathbf{7 7}$ & glabasaponin G & $\mathrm{b}$ & {$[36]$} \\
\hline
\end{tabular}

a, G. uralensis Fisch.; b, G. glabra L.; c, G. inflate Bat.

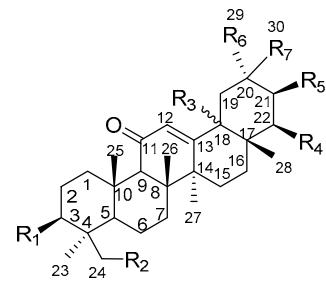

$\begin{array}{lll}R_{1} & R_{2} & R_{3}\end{array}$

$\begin{array}{llll}1 & \mathrm{~S} 3 & \mathrm{H} & \beta \mathrm{H}\end{array}$

$3 \mathrm{~S} \mathrm{H}$

$9 \mathrm{~S} 3 \mathrm{OH} \quad \beta \mathrm{H}$

$10 \mathrm{~S} 3 \mathrm{H} \quad \mathrm{BH}$

14 S3 $\mathrm{H} \quad \mathrm{aH}$

$16 \mathrm{~S} 6 \mathrm{H} \quad \mathrm{HH}$

$\begin{array}{lllll}17 & \mathrm{~S} 3 & \mathrm{H} & \mathrm{BH} & \mathrm{OCOCH}_{3}\end{array}$

$\begin{array}{lllllllllll}18 & \mathrm{~S} & \mathrm{H} & \mathrm{BH} & \mathrm{H}\end{array}$

$\begin{array}{llllll}20 & \mathrm{~S} 3 & \mathrm{H} & \mathrm{BH} & \mathrm{OH}\end{array}$

$23 \mathrm{~S} 3 \mathrm{OH} \quad \beta \mathrm{H} \quad \mathrm{OCOCH}_{3}$

$\begin{array}{lllllll}24 & \mathrm{~S} 7 & \mathrm{H} & \mathrm{BH} & \mathrm{H}\end{array}$

25 S3 $\quad \mathrm{H} \quad \beta \mathrm{H} \quad \mathrm{S}$

$\begin{array}{lllll}26 & \mathrm{~S} 15 & \mathrm{H} & \mathrm{BH} & \mathrm{S} 1\end{array}$

$\begin{array}{lllllll}28 & \mathrm{~S} 8 & \mathrm{H} & \mathrm{BH} & \mathrm{OCOCH}_{3}\end{array}$

$\begin{array}{lllllllllll}29 & \mathrm{~S} 8 & \mathrm{OH} & \beta \mathrm{H} & \mathrm{H}\end{array}$

$\begin{array}{llllll}31 & \mathrm{~S} 9 & \mathrm{H} & \mathrm{BH} & \mathrm{H}\end{array}$

$32 \mathrm{~S} 16 \mathrm{H}$

$\begin{array}{lllll}33 & \mathrm{~S} 17 & \mathrm{H} & \mathrm{BH}\end{array}$

$34 \mathrm{~S} 18 \quad \mathrm{H} \quad \mathrm{BH}$

$35 \mathrm{~S} 3 \mathrm{OH}$

$\begin{array}{llllllll}37 & \mathrm{~S} & \mathrm{H} & \mathrm{BH} & \mathrm{H}\end{array}$

$\begin{array}{llllll}38 & \mathrm{~S} 15 & \mathrm{H} & \mathrm{BH} & \mathrm{OCOCH}_{3}\end{array}$

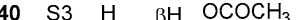

$41 \mathrm{~S} 2 \mathrm{H} \quad \mathrm{H} \quad \mathrm{H} \quad \mathrm{H}$

$\begin{array}{lllllll}47 & \mathrm{~S} 3 & \mathrm{H} & \mathrm{\beta H} & \mathrm{H} & \beta \mathrm{OH}\end{array}$

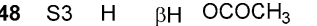

$63 \mathrm{~S} 15 \mathrm{OH} \quad \beta \mathrm{H} \quad \mathrm{OCOCH}_{3}$

$64 \quad \mathrm{~S} 13 \mathrm{OH} \quad \beta \mathrm{H} \quad \mathrm{H}$

$\begin{array}{lllll}65 & \mathrm{~S} 18 \mathrm{OH} & \beta \mathrm{H} & \mathrm{S} 2\end{array}$

$\begin{array}{llllll}66 & \mathrm{~S} 18 & \mathrm{H} & \beta \mathrm{H} & \mathrm{S} 2\end{array}$

$\begin{array}{lllll}67 & \mathrm{~S} 18 & \mathrm{H} & \beta \mathrm{H} & \mathrm{S} 2\end{array}$

$\begin{array}{llllll}68 & \mathrm{~S} 8 & \mathrm{H} & \mathrm{BH} & \mathrm{S} 2\end{array}$

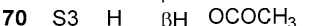

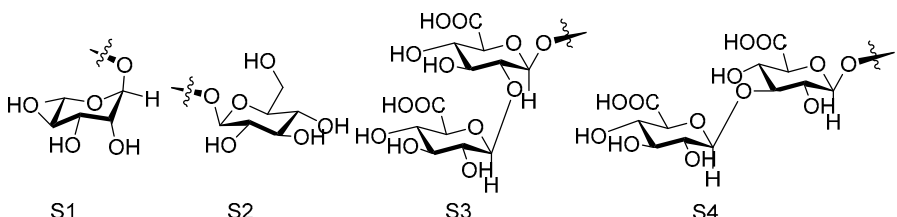

S1

S2

S3
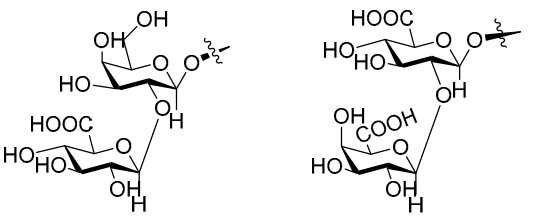

(-)

S6

S7

S8

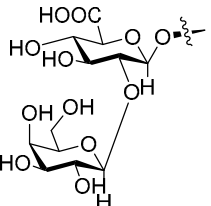

s9

$\mathrm{COOH}$

$\mathrm{COOH}$

$\mathrm{COOH}$

$\mathrm{COOH}$

$\mathrm{COOH}$

$\mathrm{COOH}$

$\mathrm{COOH}$

$\mathrm{CH}_{3}$

$\mathrm{COH}$

$\mathrm{COOH}$

$\mathrm{COH}$

$\mathrm{COOH}$

$\mathrm{COOH}$

$\mathrm{CH}_{2} \mathrm{OH}$

$\mathrm{COOH}$

$\mathrm{CO}-\mathrm{S} 2$

$\mathrm{CH}_{3}$

$\mathrm{CH}_{2} \mathrm{OH}$

$\mathrm{CH}_{3}$

$\mathrm{CH}_{3}$

$\mathrm{CH}_{3}$
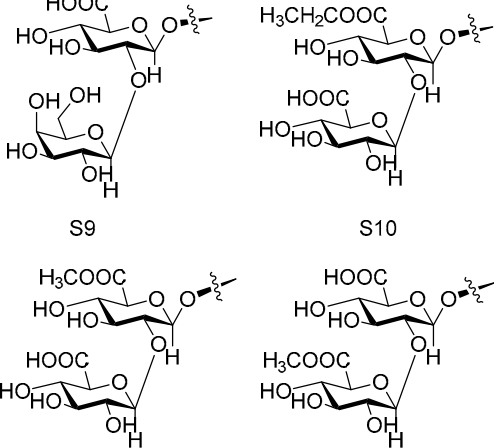

S10

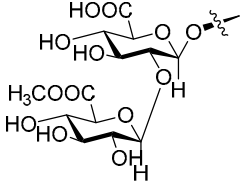

S13

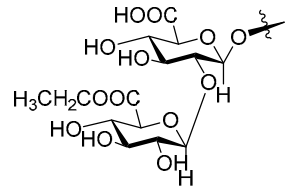

S11

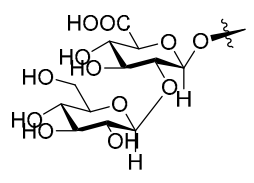

S14

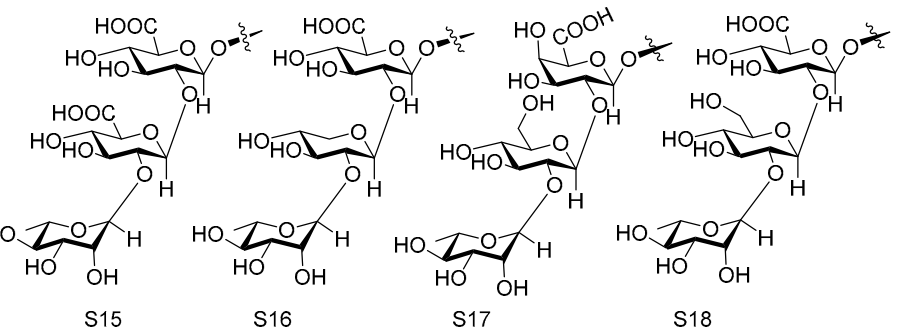

Figure 1. Cont. 

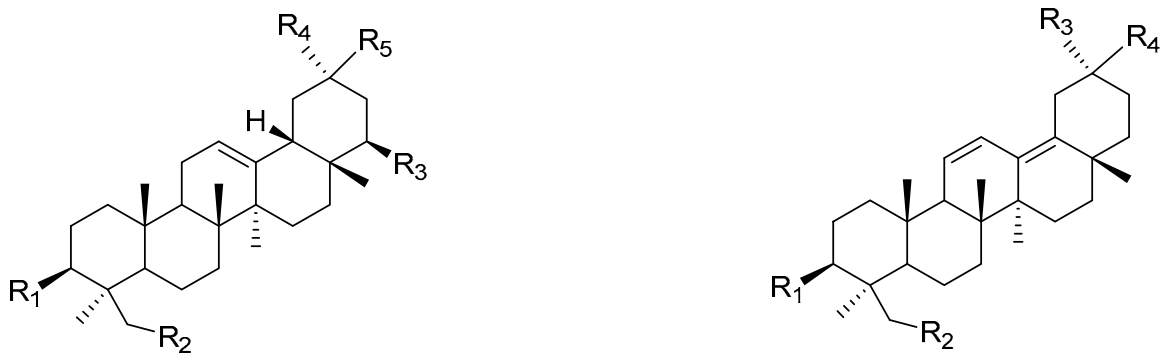

$\begin{array}{cccccc} & \mathrm{R}_{1} & \mathrm{R}_{2} & \mathrm{R}_{3} & \mathrm{R}_{4} & \mathrm{R}_{5} \\ \mathbf{4} & \mathrm{S} 3 & \mathrm{H} & \mathrm{H} & \mathrm{CH}_{3} & \mathrm{COOH} \\ \mathbf{6} & \mathrm{S} 15 & \mathrm{H} & \mathrm{OCOCH} & \mathrm{CH}_{3} & \mathrm{COOH} \\ \mathbf{1 1} & \mathrm{S} 3 & \mathrm{OH} & \mathrm{H} & \mathrm{CH}_{3} & \mathrm{COOH} \\ \mathbf{1 3} & \mathrm{S} 19 & \mathrm{OH} & \mathrm{OCOCH}_{3} & \mathrm{CH}_{3} & \mathrm{COOH}\end{array}$

$\begin{array}{ccccc} & \mathrm{R}_{1} & \mathrm{R}_{2} & \mathrm{R}_{3} & \mathrm{R}_{4} \\ \mathbf{5} & \mathrm{S} 3 & \mathrm{H} & \mathrm{CH}_{3} & \mathrm{COOH} \\ \mathbf{1 2} & \mathrm{S} 3 & \mathrm{OH} & \mathrm{CH}_{3} & \mathrm{COOH} \\ \mathbf{3 6} & \mathrm{S} 3 & \mathrm{H} & \mathrm{COOH} & \mathrm{CH}_{3}\end{array}$

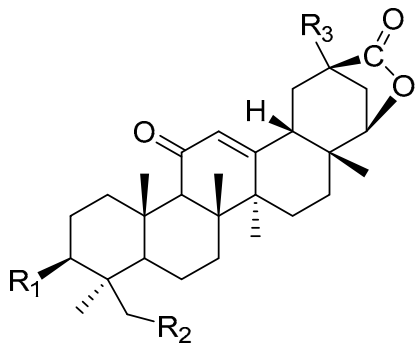

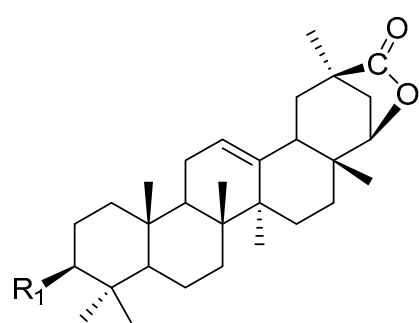

$\begin{array}{cccc} & \mathrm{R}_{1} & \mathrm{R}_{2} & \mathrm{R}_{3} \\ \mathbf{7} & \mathrm{S} 3 & \mathrm{H} & \mathrm{CH}_{3} \\ \mathbf{2 1} & \mathrm{S} 3 & \mathrm{H} & \mathrm{COOH} \\ \mathbf{2 2} & \mathrm{S} 3 & \mathrm{H} & \mathrm{CH}_{2} \mathrm{OH} \\ \mathbf{3 0} & \mathrm{S} 8 & \mathrm{H} & \mathrm{CH}_{3} \\ \mathbf{3 9} & \mathrm{S} 15 & \mathrm{H} & \mathrm{CH}_{3} \\ \mathbf{4 2} & \mathrm{S} 13 & \mathrm{OH} & \mathrm{CH}_{3}\end{array}$

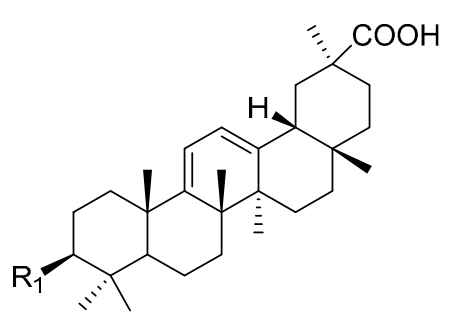

$19 \quad R_{1}=S 3$

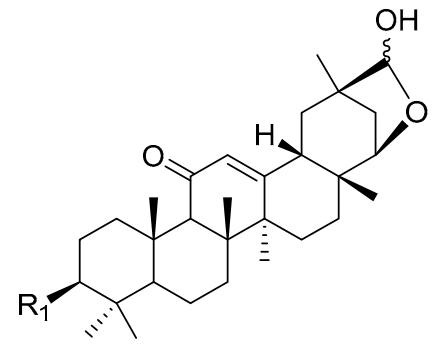

$69 \quad R_{1}=S 3$

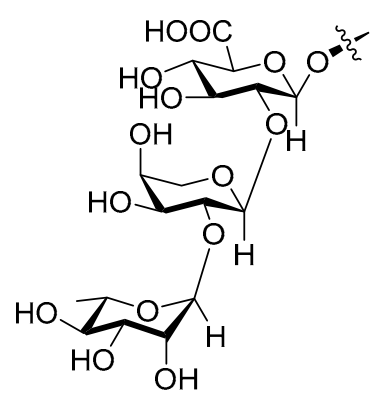

S19

Figure 1. Triterpene saponins in G. uralensis. 


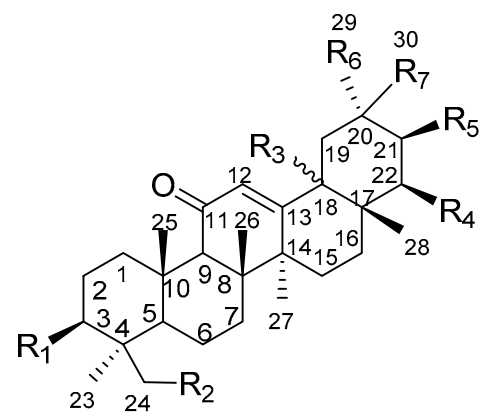

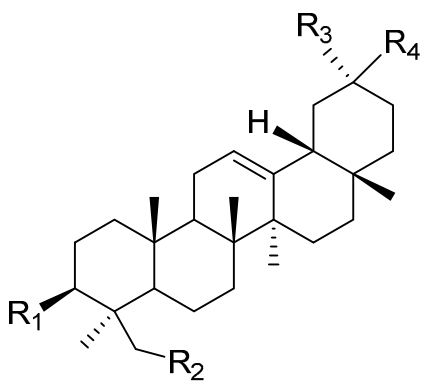

\begin{tabular}{|c|c|c|c|c|c|c|c|c|c|c|c|c|}
\hline 1 & $\begin{array}{l}R_{1} \\
S 3\end{array}$ & $\begin{array}{c}\mathrm{R}_{2} \\
\mathrm{H}\end{array}$ & $\begin{array}{l}\mathrm{R}_{3} \\
\mathrm{BH}\end{array}$ & $\begin{array}{l}\mathrm{R}_{4} \\
\mathrm{H}\end{array}$ & $\begin{array}{l}\mathrm{R}_{5} \\
\mathrm{H}\end{array}$ & $\begin{array}{l}\mathrm{R}_{6} \\
\mathrm{CH}_{3}\end{array}$ & $\begin{array}{c}\mathrm{R}_{7} \\
\mathrm{COOH}\end{array}$ & 4 & $\begin{array}{l}\mathrm{R}_{1} \\
\mathrm{~S} 3\end{array}$ & $\begin{array}{l}\mathrm{R}_{2} \\
\mathrm{H}\end{array}$ & $\begin{array}{l}\mathrm{R}_{3} \\
\mathrm{CH}_{3}\end{array}$ & $\begin{array}{c}\mathrm{R}_{4} \\
\mathrm{COOH}\end{array}$ \\
\hline 2 & S4 & $\mathrm{H}$ & $\beta \mathrm{H}$ & $\mathrm{H}$ & $\mathrm{H}$ & $\mathrm{CH}_{3}$ & $\mathrm{COOH}$ & 11 & S3 & $\mathrm{OH}$ & $\mathrm{CH}_{3}$ & $\mathrm{COOH}$ \\
\hline 9 & S3 & $\mathrm{OH}$ & $\beta \mathrm{H}$ & $\mathrm{H}$ & $\mathrm{H}$ & $\mathrm{CH}_{3}$ & $\mathrm{COOH}$ & 57 & $\mathrm{~S} 15$ & $\mathrm{H}$ & $\mathrm{CH}_{3}$ & $\mathrm{COO}$ \\
\hline $\begin{array}{l}10 \\
14\end{array}$ & $\begin{array}{l}\text { S3 } \\
\text { S3 }\end{array}$ & $\begin{array}{l}\mathrm{H} \\
\mathrm{H}\end{array}$ & $\begin{array}{l}\beta \mathrm{H} \\
\alpha \mathrm{H}\end{array}$ & $\begin{array}{l}\mathrm{H} \\
\mathrm{H}\end{array}$ & $\begin{array}{l}\mathrm{H} \\
\mathrm{H}\end{array}$ & $\begin{array}{c}\mathrm{COOH} \\
\mathrm{CH}_{3}\end{array}$ & $\begin{array}{c}\mathrm{CH}_{3} \\
\mathrm{COOH}\end{array}$ & 60 & S3 & $\mathrm{H}$ & $\mathrm{COOH}$ & $\mathrm{CH}_{3}$ \\
\hline 15 & S5 & $\mathrm{H}$ & $\beta \mathrm{H}$ & $\mathrm{H}$ & $\mathrm{H}$ & $\mathrm{CH}_{3}$ & $\mathrm{COOH}$ & & & & & \\
\hline 16 & S6 & $\mathrm{H}$ & $\beta \mathrm{H}$ & $\mathrm{H}$ & $\mathrm{H}$ & $\mathrm{CH}_{3}$ & $\mathrm{COOH}$ & & & & & $R_{4}$ \\
\hline 25 & S3 & $\mathrm{H}$ & $\beta \mathrm{H}$ & S1 & $\mathrm{H}$ & $\mathrm{CH}_{3}$ & $\mathrm{COOH}$ & & & & & \\
\hline 26 & S15 & $\mathrm{H}$ & $\beta \mathrm{H}$ & S1 & $\mathrm{H}$ & $\mathrm{CH}_{3}$ & $\mathrm{COOH}$ & & & & & \\
\hline 27 & S15 & $\mathrm{OH}$ & $\beta \mathrm{H}$ & S1 & $\mathrm{H}$ & $\mathrm{CH}_{3}$ & $\mathrm{COOH}$ & & & & & \\
\hline 41 & S2 & $\mathrm{H}$ & $\beta \mathrm{H}$ & $\mathrm{H}$ & $\mathrm{H}$ & $\mathrm{CH}_{3}$ & $\mathrm{COOH}$ & & & & & \\
\hline 45 & S3 & $\mathrm{H}$ & $\beta \mathrm{H}$ & $\mathrm{H}$ & $\alpha \mathrm{OH}$ & $\mathrm{COOH}$ & $\mathrm{CH}_{3}$ & & & & & \\
\hline 49 & S10 & $\mathrm{H}$ & $\beta \mathrm{H}$ & $\mathrm{H}$ & $\mathrm{H}$ & $\mathrm{CH}_{3}$ & $\mathrm{COOH}$ & & & & & \\
\hline 50 & S11 & $\mathrm{H}$ & $\beta \mathrm{H}$ & $\mathrm{H}$ & $\mathrm{H}$ & $\mathrm{CH}_{3}$ & $\mathrm{COOH}$ & & & $2_{2}$ & & \\
\hline 51 & $\mathrm{~S} 12$ & $\mathrm{OH}$ & $\beta \mathrm{H}$ & $\mathrm{H}$ & $\mathrm{H}$ & $\mathrm{CH}_{3}$ & $\mathrm{COOH}$ & & $\mathrm{R}_{1}$ & $\mathrm{R}_{2}$ & $\mathrm{R}_{3}$ & $\mathrm{R}_{4}$ \\
\hline 52 & $\mathrm{~S} 13$ & $\mathrm{H}$ & $\beta \mathrm{H}$ & $\mathrm{H}$ & $\mathrm{H}$ & $\mathrm{CH}_{3}$ & $\mathrm{COOH}$ & 5 & $\begin{array}{l}\mathrm{N} \\
\mathrm{S} 3\end{array}$ & $\mathrm{H}$ & $\mathrm{CH}_{3}$ & $\mathrm{COOH}$ \\
\hline $\begin{array}{l}53 \\
54\end{array}$ & $\begin{array}{l}\text { S3 } \\
\text { S3 }\end{array}$ & $\begin{array}{l}\mathrm{H} \\
\mathrm{H}\end{array}$ & $\begin{array}{l}\beta \mathrm{H} \\
\beta \mathrm{H}\end{array}$ & $\begin{array}{l}\mathrm{H} \\
\mathrm{H}\end{array}$ & $\begin{array}{l}\mathrm{H} \\
\mathrm{H}\end{array}$ & $\begin{array}{l}\mathrm{CH}_{3} \\
\mathrm{CH}_{3}\end{array}$ & $\begin{array}{c}\mathrm{CH}_{2} \mathrm{OH} \\
\mathrm{CH}_{2} \mathrm{OCOH}\end{array}$ & 12 & S3 & $\mathrm{OH}$ & $\mathrm{CH}_{3}$ & $\mathrm{COOH}$ \\
\hline 55 & S14 & $\mathrm{OH}$ & $\beta \mathrm{H}$ & $\mathrm{H}$ & $\mathrm{H}$ & $\mathrm{CH}_{3}$ & $\mathrm{COOH}$ & 36 & S3 & $\mathrm{H}$ & $\mathrm{COOH}$ & $\mathrm{CH}_{3}$ \\
\hline 56 & S15 & $\mathrm{H}$ & $\beta \mathrm{H}$ & $\mathrm{H}$ & $\mathrm{H}$ & $\mathrm{CH}_{3}$ & $\mathrm{COOH}$ & & & & & \\
\hline 58 & S18 & $\mathrm{H}$ & $\beta \mathrm{H}$ & $\mathrm{H}$ & $\mathrm{H}$ & $\mathrm{CH}_{3}$ & $\mathrm{COOH}$ & & & & & \\
\hline 59 & S19 & $\mathrm{H}$ & $\beta \mathrm{H}$ & $\mathrm{H}$ & $\mathrm{H}$ & $\mathrm{CH}_{3}$ & $\mathrm{COOH}$ & & & & & \\
\hline 61 & S8 & $\mathrm{H}$ & $\beta \mathrm{H}$ & $\mathrm{H}$ & $\mathrm{H}$ & $\mathrm{COOH}$ & $\mathrm{CH}_{3}$ & & & & & \\
\hline 62 & S15 & $\mathrm{H}$ & $\beta \mathrm{H}$ & $\mathrm{H}$ & $\mathrm{H}$ & $\mathrm{COOH}$ & $\mathrm{CH}_{3}$ & & & & & \\
\hline 71 & S3 & $\mathrm{OH}$ & $\beta \mathrm{H}$ & $\mathrm{H}$ & $\beta \mathrm{OH}$ & $\mathrm{COOH}$ & $\mathrm{CH}_{3}$ & & & & & \\
\hline 72 & S3 & $\mathrm{OH}$ & $\beta \mathrm{H}$ & $\mathrm{H}$ & $\alpha \mathrm{OH}$ & $\mathrm{COOH}$ & $\mathrm{CH}_{3}$ & & & & & \\
\hline 73 & S8 & $\mathrm{OH}$ & $\beta \mathrm{H}$ & $\mathrm{H}$ & $\beta$-S2 & $\mathrm{CH}_{2} \mathrm{OH}$ & $\mathrm{CH}_{3}$ & & & & & \\
\hline 74 & S8 & $\mathrm{OH}$ & $\beta \mathrm{H}$ & $\mathrm{H}$ & $\beta-S 2$ & $\mathrm{CH}_{3}$ & $\mathrm{CH}_{2} \mathrm{OH}$ & & $\mathrm{HC}$ & & $\mathrm{H}$ & \\
\hline 75 & S15 & $\mathrm{OH}$ & $\beta \mathrm{H}$ & $\mathrm{H}$ & $\beta-S 2$ & $\mathrm{CH}_{2} \mathrm{OH}$ & $\mathrm{CH}_{3}$ & & & $S 5$ & & \\
\hline 76 & S15 & $\mathrm{OH}$ & $\beta \mathrm{H}$ & $\mathrm{H}$ & $\beta-\mathrm{S} 2$ & $\mathrm{CH}_{3}$ & $\mathrm{CH}_{2} \mathrm{OH}$ & & & & & \\
\hline 77 & S3 & $\mathrm{H}$ & $\beta \mathrm{H}$ & $\mathrm{H}$ & $\alpha \mathrm{OH}$ & $\mathrm{CH}_{2} \mathrm{OH}$ & $\mathrm{COOH}$ & & & & & \\
\hline
\end{tabular}

Figure 2. Triterpene saponins in G. glabra. 


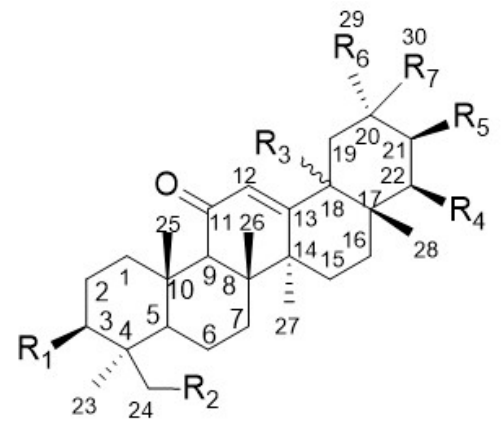

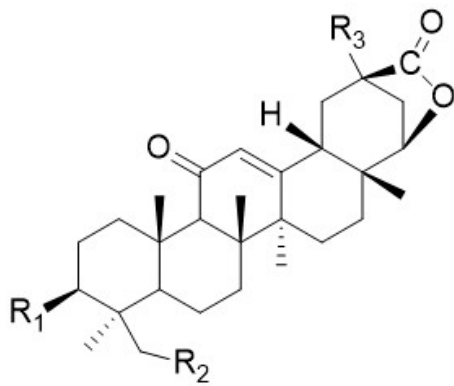

$\begin{array}{cccccccc} & \mathrm{R}_{1} & \mathrm{R}_{2} & \mathrm{R}_{3} & \mathrm{R}_{4} & \mathrm{R}_{5} & \mathrm{R}_{6} & \mathrm{R}_{7} \\ \mathbf{1} & \mathrm{S} 3 & \mathrm{H} & \mathrm{H} & \mathrm{H} & \mathrm{H} & \mathrm{CH}_{3} & \mathrm{COOH} \\ 3 & \mathrm{~S} 3 & \mathrm{H} & \beta \mathrm{H} & \mathrm{H} & \mathrm{H} & \mathrm{CH}_{3} & \mathrm{CO}-\mathrm{S} 2 \\ \mathbf{9} & \mathrm{S} 3 & \mathrm{OH} & \beta \mathrm{H} & \mathrm{H} & \mathrm{H} & \mathrm{CH}_{3} & \mathrm{COOH} \\ 15 & \mathrm{~S} 5 & \mathrm{H} & \beta \mathrm{H} & \mathrm{H} & \mathrm{H} & \mathrm{CH}_{3} & \mathrm{COOH} \\ 16 & \mathrm{~S} 6 & \mathrm{H} & \beta \mathrm{H} & \mathrm{H} & \mathrm{H} & \mathrm{CH}_{3} & \mathrm{COOH} \\ 17 & \mathrm{~S} 3 & \mathrm{H} & \beta \mathrm{H} & \mathrm{OCOCH}_{3} & \mathrm{H} & \mathrm{CH}_{3} & \mathrm{COOH} \\ \mathbf{4 0} & \mathrm{S} 3 & \mathrm{H} & \beta \mathrm{H} & \mathrm{OCOCH}_{3} & \mathrm{H} & \mathrm{CH}_{3} & \mathrm{COH} \\ \mathbf{4 3} & \mathrm{S} 3 & \mathrm{H} & \beta \mathrm{H} & \mathrm{H} & \mathrm{H} & \mathrm{CH}_{2} \mathrm{OH} & \mathrm{COOH} \\ \mathbf{4 4} & \mathrm{S} 3 & \mathrm{OH} & \alpha \mathrm{H} & \mathrm{H} & \mathrm{H} & \mathrm{CH}_{3} & \mathrm{COOH} \\ \mathbf{4 5} & \mathrm{S} 3 & \mathrm{H} & \beta \mathrm{H} & \mathrm{H} & \alpha \mathrm{OH} & \mathrm{COOH}^{\mathrm{COH}} & \mathrm{CH}\end{array}$

$\begin{array}{cccc} & \mathrm{R}_{1} & \mathrm{R}_{2} & \mathrm{R}_{3} \\ 7 & \mathrm{~S} 3 & \mathrm{H} & \mathrm{CH}_{3} \\ \mathbf{2 1} & \mathrm{S} 3 & \mathrm{H} & \mathrm{COOH} \\ \mathbf{4 6} & \mathrm{S} 3 & \mathrm{OH} & \mathrm{CH}_{3}\end{array}$

Figure 3. Triterpene saponins in G. inflata.

From the point of view of chemical structure, the aglycons of most oleanane-type pentacyclic triterpene saponins in glycyrrhiza possess an $\alpha, \beta$-unsaturated ketone unit located at C-11, C-12, and C-13. Notably, some glabrolides $(7,21,22,30,39,42$, and 46) were found in $G$. uralensis or/and $G$. inflate, which possess a 22 (30)-lactone ring alongside an $\alpha, \beta$-unsaturated ketone unit. The sugar moiety of oleanane-type pentacyclic triterpene saponins in glycyrrhiza contains six basic sugar residues, including glucuronic acid residue (GluA), rhamnose residue (Rha), glucose residue (Glu), galacturonic acid residue (GalA), xylose residue $(\mathrm{Xyl})$, and galactose residue (Gal). Moreover, apioglycyrrhizin (15) contains an apiofuranose residue and araboglycyrrhizin (16) contains an arabinose residue (Ara). Furthermore, all triterpene saponins in glycyrrhiza are linked to sugar groups at C-3; the glycoside bound to $\mathrm{C}-3$ of the aglycon possesses the $\beta$-configuration. Among them, the $\mathrm{C}-21$ linked to glycoside is the $\beta$-configuration (73-76), while the hydroxyl group at C-21 has both the $\alpha$-configuration and $\beta$-configuration.

Glycyrrhizin (GL, 1) (also named glycyrrhizic acid, uralsaponin A, and 18 $\beta$-glycyrrhizic acid) is one of the most representative saponins of glycyrrhiza, isolated from the roots of both G. uralensis Fisch. [16], G. glabra L. [19], and G. inflata Batal. [20]. Zapesochnaya et al. [37] demonstrated the differences between the NMR spectra of the $18 \alpha$-epimer of GL and the $18 \beta$-epimer. Normally, $18 \beta$-glycyrrhizic acid is the principal chemical composition, while $18 \alpha$-glycyrrhizic acid is rare [38]. Licorice-saponin Q2 (44) was previously isolated from the roots of G. inflata. Analysis of its Nuclear Overhauser Effect Spectroscopy (NOESY) spectrum showed that $\mathrm{H}-18$ correlated with $\mathrm{H}-19 \alpha$ and $\mathrm{H}-29\left(\mathrm{CH}_{3}\right)$, indicating that $\mathrm{H}-18$ of 44 was $\alpha$-oriented. In addition, similar triterpene saponins, such as licorice-saponin G2 (9) and araboglycyrrhizin (16), were also observed in G. uralensis, G. glabra, and G. inflate. Eleven triterpene saponins $(2,4,5,10-12,14,25,26,36$, and 41) were also found both in G. uralensis and G. glabra, including uralsaponin B (2) [16,21], licorice-saponin B2 (4) [22,23], licorice-saponin C2 (5) [22,23], licorice-saponin H2 (10) [23,24], licorice-saponin J2 (11) [23,24], licorice-saponin K2 (12) [21,24], $18 \alpha$-glycyrrhizic acid (14) [17], licorice-saponin M3 or uralsaponin T (25) [27,31], licorice-saponin N4 (26) [31,32], uralsaponin V (36) [21,27], and 3-O- $\beta$-D-glucuronopyranosylglycyrrhetinic acid (41) [21,27]. 
Licorice-saponin M3, and uralsaponin T were previously reported as new oleanane-type triterpene saponins, but they are the same compounds.

\subsection{Biological Activities}

Modern pharmacological studies revealed that glycyrrhiza shows a variety of pharmacological effects against inflammation, oxidative stress, immunoregulation, viral infection, and cancer [3]. These bioactivities are attributed to the chemical constituents of glycyrrhiza. In this section, the main pharmacological activities of saponin monomers, including hepatoprotective, anti-inflammatory, antimicrobial, antiviral, and antitumor activities, are summarized (Table 2). GL (1) is the most commonly reported monomer with extensive activities.

\subsubsection{Hepatoprotective Activities}

There are many reports about possible mechanisms in vitro and vivo by which saponins from glycyrrhiza are hepatoprotective. GL (1) was proven to relieve liver disease and prevent drug-induced liver injury through multitargeting therapeutic mechanisms, including antisteatosis, antioxidative stress, anti-inflammation, immunoregulation, antifibrosis, anticancer, and drug-drug interactions [3]. Nakamura et al. [39] reported that GL (1) prevented soluble enzyme release from primary cultured rat hepatocytes induced by $\mathrm{CCl}_{4}$. Sato et al. [40] found that GL (1) could modify the expression of hepatitis $B$ virus (HBV)-related antigens on the hepatocytes and suppress sialylation of hepatitis B surface antigen (HBsAg) in PLC/PRF/5 cells. Tsuruoka et al. [41] showed that GL (1, $10.5 \mathrm{mg} / \mathrm{kg})$ suppressed increases in aspartate aminotransaminase (AST) and alanine aminotransaminase (ALT), inhibited inducible nitric oxide synthase (iNOS) mRNA expression, and reduced protein and cell infiltration and the degeneration of hepatocytes in the liver of concanavalin A (Con A)-treated BALB/c mice. Lee et al. [42] reported that GL (1) alleviated carbon tetrachloride $\left(\mathrm{CCl}_{4}\right)$-induced liver injury in ICR mice, probably by inducing heme oxygenase- 1 and downregulating proinflammatory mediators. Lin et al. [43] found that a three-day pretreatment with GL (1) exhibited a protective effect on retrorsine-induced liver damage in Sprague Dawley rats. GL (1) is able to provide partial protection of the liver against ischemia-reperfusion damage in Wistar rats [44]. Orazizadeh et al. [45] showed that GL (1) effectively protects against $\mathrm{NTiO}_{2}$-induced hepatotoxicity in Wistar rats.

In addition, some other triterpenoid saponins in glycyrrhiza also exhibited hepatoprotective activities. Glyuralsaponin B (64) and glyuralsaponin H (70) exhibited moderate antioxidant activities against $\mathrm{Fe}^{2+} /$ cysteine-induced liver microsomal lipid peroxidation at a concentration of $0.1 \mu \mathrm{M}$ (curcumin as positive control) [32]. It was reported that GL (1), licorice-saponin G2 (9), $22 \beta$-acetoxylglycyrrhizin (17), licorice-saponin Q2 (44), and macedonoside A (45) showed significant hepatoprotective activities by lowering ALT and AST levels in primary rat hepatocytes injured by D-galactosamine (D-GalN) in a concentration range of 30-120 $\mu \mathrm{M}$. Besides, GL (1), licorice-saponin G2 (9), 22 $\beta$-acetoxylglycyrrhizin (17), uralsaponin D (21), licorice-saponin Q2 (44), and macedonoside A (45) were found to potently inhibit the activity of phospholipase A2 (PLA 2 ) with $\mathrm{IC}_{50}$ values of $9.3 \mu \mathrm{M}$, $16.9 \mu \mathrm{M}, 27.1 \mu \mathrm{M}, 32.2 \mu \mathrm{M}, 3.6 \mu \mathrm{M}$, and $6.9 \mu \mathrm{M}$, respectively, which might be involved in the regulation of the hepatoprotective activities observed. [20].

\subsubsection{Anti-Inflammatory Activities}

In a study, Li et al. [46] suggested that the anti-inflammatory mechanism of total saponins of glycyrrhiza may be related to a reduction in the release of inflammation factors in macrophages and inhibition of the key enzymes in the arachidonic acid (AA) metabolism pathway of prostaglandin E2 (PGE 2 ) synthesis, as observed through an inflammatory model of mouse macrophage RAW264.7 cells induced by lipopolysaccharide (LPS). Wang et al. [47] investigated the anti-inflammatory effect of GL (1) on LPS-stimulated mouse endometrial epithelial cells (MEEC), demonstrating that GL (1) inhibited LPS-induced inflammatory response by inhibiting TLR4 signaling pathway in MEEC. 
Akamatsu et al. [48] found that GL (1) inhibited reactive oxygen species (ROS) generation by neutrophils, which were potent inflammatory mediators in the in vitro study.

In addition, GL (1) may inhibit high-mobility group protein B1 (HMGB1) expression and subsequent production of inflammatory cytokines to prevent cerebral vasospasm (CVS) following subarachnoid hemorrhage (SAH) in Sprague-Dawley rats [49]. Pang et al. [50] demonstrated that inhibiting HMGB1 with GL (1) alleviated brain injury after diffuse axonal injury (DAI) via its anti-inflammatory effects in SD rats.

\subsubsection{Antimicrobial and Antiviral Activities}

Saponins of G. glabra L. have broad-spectrum antimicrobial activities and can be used as natural antimicrobial agents [51]. GL (1) is an effective antiviral component against hepatitis $C$ virus (HCV), human immunodeficiency virus (HIV), coxsackie virus B3 (CVB3), duck hepatitis virus (DHV), enterovirus 71 (EV71), coxsackievirus A16 (CVA16), herpes simplex virus (HSV), and H5N1 by weakening viral activity and enhancing host cell activity [52]. GL (1) is also shown to inhibit varicella zoster virus (VZV) and the severe acute respiratory syndrome coronavirus (SARS-CoV) replication in vitro [53,54]. In another study, Wolkerstorfer et al. [55] found that GL (1) inhibited influenza A virus (IAV) uptake into the cell. In detail, Sun et al. [56] summarized the antiviral effects of GL (1) in their research regarding progress and mechanism in recent years.

At present, the world is facing the Corona Virus Disease 2019 (COVID-19) pandemic, caused by severe acute respiratory syndrome coronavirus-2 (SARS-CoV-2). GL (1) has been used to control COVID-19 infections, which may reduce the severity of an infection with COVID-19 at the two stages of the COVID-19-induced disease process: 1 . to block the number of entry points and 2. to provide an angiotensin converting enzyme 2 (ACE2)-independent anti-inflammatory mechanism. [57]. In vitro assays of $22 \beta$-acetoxyglycyrrhizin (17), uralsaponin T (25), uralsaponin M (28), and uralsaponin S (34) exhibited good inhibitory activities against influenza virus A/WSN/33 (H1N1) in Madin-Darby canine kidney (MDCK) cells (using Oseltamivir phosphate as a positive control drug) [27]. In addition, GA (1), licorice-saponin A3 (3), licorice-saponin G2 (9), 22ß-acetoxylglycyrrhizin (17), and licorice-saponin M3 (25) were shown to possess moderate influenza neuraminidase (NA)-inhibitory activity by the commercial NA inhibitory screening kit, although the measured activity was lower than that of Oseltamivir [31].

\subsubsection{Cytotoxic and Antitumor Activities}

Deng et al. [58] showed that GL (1) profoundly reduced expression of thromboxane synthase (TxAS), as well as proliferating cell nuclear antigen (PCNA), and rescued liver and kidney damage in tumor-bearing mice, the effect of which is possibly through suppression of the TxA2 pathway. It was shown that GL (1) has protective effects against Aflatoxin B1 ( $\left.\mathrm{AFB}_{1}\right)$-induced cytotoxicity in human hepatoma cell line (HepG2) [59]. In addition, dipotassium glycyrrhizinate (DPG), a dipotassium salt of GL, presented antitumoral effects on glioblastoma (GBM) cell lines through decreased proliferation and increased apoptosis. The DPG antitumoral effect is related to NF- $\kappa \mathrm{B}$ suppression, where IRAK2- and TRAF6-mediating miR16 and miR146a, respectively, might be potential therapeutic targets of DPG [60].

In the cytotoxic assay, GL (1), licorice-saponin G2 (9) and uralsaponin D (21), showed no cytotoxic activity on tested cancer cell lines, whereas their corresponding aglycones exhibited potently cytotoxic activities against human cervical cancer HeLa cells and human breast adenocarcinoma MCF-7 cells [29]. 
Table 2. Summary of the biological activities conducted with triterpene saponins in glycyrrhiza ${ }^{1}$.

\begin{tabular}{|c|c|c|c|c|c|}
\hline \multirow{2}{*}{ No. } & \multirow{2}{*}{ Compound } & \multicolumn{3}{|c|}{ Activity } & \multirow{2}{*}{ References } \\
\hline & & Property & Method & Major Findings & \\
\hline \multirow{21}{*}{1} & \multirow{21}{*}{$\begin{array}{c}\text { glycyrrhizin } \\
\text { (glycyrrhizic acid, } \\
\text { uralsaponin A or } \\
\text { 18ß-glycyrrhizic acid) }\end{array}$} & \multirow{9}{*}{ Hepatoprotective activities } & $\begin{array}{c}\text { In vitro-primary rat hepatocytes injured by } \\
\text { D-galactosamine (D-GalN) }\end{array}$ & $\begin{array}{l}\text { Lower alanine aminotransaminase (ALT) and aspartate aminotransaminase } \\
\text { (AST) levels }\end{array}$ & [20] \\
\hline & & & PLA $_{2}$ inhibitory potency & $\mathrm{IC}_{50}=9.3 \mu \mathrm{M}$ & [20] \\
\hline & & & $\begin{array}{l}\text { In vitro-primary cultured rat hepatocytes } \\
\text { induced by } \mathrm{CCl}_{4}\end{array}$ & Prevent soluble enzyme release & [39] \\
\hline & & & In vitro-PLC/PRF/5 cells & $\begin{array}{l}\text { Modify the expression of hepatitis B virus (HBV)-related antigens on the } \\
\text { hepatocytes and suppress sialylation of HBsAg }\end{array}$ & [40] \\
\hline & & & In vivo-BALB/c mice & $\begin{array}{l}\text { Suppress increases in AST and ALT, inhibit inducible nitric oxide synthase } \\
\text { (iNOS) mRNA expression, and reduce protein and cell infiltration and the } \\
\text { degeneration of hepatocytes }\end{array}$ & [41] \\
\hline & & & In vivo-ICR mice & Alleviate $\mathrm{CCl}_{4}$-induced liver injury & [42] \\
\hline & & & In vivo-Sprague Dawley rats & Exhibit protective effect on retrorsine-induced liver damage & [43] \\
\hline & & & In vivo-Wistar rats & Provide partial protection of the liver against ischemia-reperfusion damage & [44] \\
\hline & & & In vivo-Wistar rats & Protect against $\mathrm{NTiO}_{2}$-induced hepatotoxicity & [45] \\
\hline & & \multirow{4}{*}{ Anti-inflammatory activities } & $\begin{array}{c}\text { In vitro-lipopolysaccharide } \\
\text { (LPS)-stimulated mouse endometrial } \\
\text { epithelial cells (MEEC) }\end{array}$ & $\begin{array}{l}\text { Inhibit LPS-induced inflammatory response by inhibiting TLR4 } \\
\text { signaling pathway }\end{array}$ & [47] \\
\hline & & & In vitro-neutrophil & Inhibit reactive oxygen species (ROS) generation by neutrophils & [48] \\
\hline & & & In vivo-Sprague Dawley rats & $\begin{array}{c}\text { Inhibit HMGB1 expression and subsequent production of inflammatory } \\
\text { cytokines to prevent cerebral vasospasm (CVS) following subarachnoid } \\
\text { hemorrhage (SAH) }\end{array}$ & [49] \\
\hline & & & In vivo-SD rats & $\begin{array}{l}\text { Alleviate brain injury after diffuse axonal injury (DAI) via its } \\
\text { anti-inflammatory effects }\end{array}$ & [50] \\
\hline & & \multirow{5}{*}{ Antimicrobial and antiviral activities } & In vitro & Inhibit varicella zoster virus (VZV) & [53] \\
\hline & & & In vitro & Inhibit severe acute respiratory syndrome coronavirus (SARS-CoV) replication & [54] \\
\hline & & & In vitro & Inhibited influenza A virus (IAV) uptake into the cell & [55] \\
\hline & & & In vitro & $\begin{array}{l}\text { Reduce the severity of an infection with COVID-19 at the two stages of the } \\
\text { COVID-19 induced disease process, } 1 \text {. To block the number of entry points } \\
\text { and 2. provide an ACE2 independent anti-inflammatory mechanism. }\end{array}$ & [57] \\
\hline & & & The commercial NA inhibitory screening kit & Possess moderate influenza NA inhibitory activity & [31] \\
\hline & & \multirow[t]{2}{*}{ Cytotoxic and antitumor activities } & In vivo-tumor-bearing mice & $\begin{array}{l}\text { Reduce expression of TxAS, as well as proliferating cell nuclear antigen } \\
\text { (PCNA), and rescue liver and kidney damage }\end{array}$ & [58] \\
\hline & & & In vitro-HepG2 & Display protective effects against Aflatoxin $\mathrm{B} 1\left(\mathrm{AFB}_{1}\right)$-induced cytotoxicity & [59] \\
\hline & & Other activities & - & $\begin{array}{l}\text { 1. Possess immunomodulatory, neuroprotective effects, and antioxidant } \\
\text { activities; 2. Bronchitis, peptic ulcers, skin diseases, and oral diseases; } 3 \text {. } \\
\text { Allergic rhinitis }\end{array}$ & {$[56,61-66]$} \\
\hline
\end{tabular}


Table 2. Cont

\begin{tabular}{|c|c|c|c|c|c|}
\hline \multirow{2}{*}{ No. } & \multirow{2}{*}{ Compound } & \multicolumn{3}{|c|}{ Activity } & \multirow{2}{*}{ References } \\
\hline & & Property & Method & Major Findings & \\
\hline 3 & licorice-saponin $\mathrm{A} 3$ & Antimicrobial and antiviral activities & The commercial NA inhibitory screening kit & Possess moderate influenza NA inhibitory activity & [31] \\
\hline \multirow{3}{*}{9} & \multirow{3}{*}{ licorice-saponin G2 } & \multirow{2}{*}{ Hepatoprotective activities } & $\begin{array}{l}\text { In vitro-primary rat hepatocytes injured by } \\
\text { D-GalN }\end{array}$ & Lower ALT and AST levels & [20] \\
\hline & & & $\mathrm{PLA}_{2}$ inhibitory potency & $\mathrm{IC}_{50}=16.9 \mu \mathrm{M}$ & [20] \\
\hline & & Antimicrobial and antiviral activities & The commercial NA inhibitory screening kit & Possess moderate influenza NA inhibitory activity & [31] \\
\hline \multirow{4}{*}{17} & \multirow{4}{*}{$22 \beta$-acetoxylglycyrrhizin } & \multirow[t]{2}{*}{ Hepatoprotective activities } & $\begin{array}{l}\text { In vitro-primary rat hepatocytes injured by } \\
\text { D-GalN }\end{array}$ & Lower ALT and AST levels & [20] \\
\hline & & & PLA $_{2}$ inhibitory potency & $\mathrm{IC}_{50}=27.1 \mu \mathrm{M}$ & [20] \\
\hline & & \multirow{2}{*}{ Antimicrobial and antiviral activities } & $\begin{array}{l}\text { In vitro-Madin-Darby canine kidney } \\
\text { (MDCK) cells }\end{array}$ & Inhibit influenza virus A/WSN/33 (H1N1) & [27] \\
\hline & & & The commercial NA inhibitory screening kit & Possess moderate influenza NA inhibitory activity & [31] \\
\hline 21 & uralsaponin D & Hepatoprotective activities & $\mathrm{PLA}_{2}$ inhibitory potency & $\mathrm{IC}_{50}=32.2 \mu \mathrm{M}$ & [20] \\
\hline \multirow{2}{*}{25} & \multirow{2}{*}{$\begin{array}{l}\text { licorice-saponin } \\
\text { M3(uralsaponin T) }\end{array}$} & \multirow{2}{*}{ Antimicrobial and antiviral activities } & In vitro-MDCK cells & Inhibit influenza virus A/WSN/33 (H1N1) & [27] \\
\hline & & & The commercial NA inhibitory screening kit & Possess moderate influenza NA inhibitory activity & [31] \\
\hline 28-39 & uralsaponins $\mathrm{M}-\mathrm{Y}$ & Antimicrobial and antiviral activities & In vitro-MDCK cells & $\begin{array}{c}\text { Uralsaponin M (28) and uralsaponin S (34) exhibited inhibitory activities } \\
\text { against influenza virus A/WSN/33 (H1N1) }\end{array}$ & [27] \\
\hline \multirow[t]{2}{*}{$44-45$} & \multirow{2}{*}{$\begin{array}{l}\text { licorice-saponin Q2 (44) } \\
\text { macedonoside A (45) }\end{array}$} & \multirow[t]{2}{*}{ Hepatoprotective activities } & $\begin{array}{l}\text { In vitro-primary rat hepatocytes injured } \\
\text { by D-GalN }\end{array}$ & Lower ALT and AST levels & [20] \\
\hline & & & $\mathrm{PLA}_{2}$ inhibitory potency & $\mathrm{IC}_{50}=3.6 \mu \mathrm{M}(44)$ and $6.9 \mu \mathrm{M}(45)$ & [20] \\
\hline 63-70 & glyuralsaponins A-H & Hepatoprotective activities & MDA colorimetric assay & $\begin{array}{l}\text { Glyuralsaponin B (64) and glyuralsaponin } \mathrm{H}(70) \text { exhibited moderate } \\
\text { antioxidant activities against } \mathrm{Fe}^{2+} \text { /cysteine-induced liver microsomal lipid } \\
\text { peroxidation }\end{array}$ & [32] \\
\hline
\end{tabular}

${ }^{1}$, Columns 1 and 2 is the same in Table 1. It should be noted that the empty rows with triterpene saponins are grouped together or not listed in Table 2. 


\subsubsection{Other Activities}

Saponin monomers of glycyrrhiza were shown to have various other physiological and pharmacological activities. GL (1) also possesses immunomodulatory, and neuroprotective effects [61] and antioxidant activities [62,63]. Furthermore GL (1) can be used in the clinical treatment of bronchitis, peptic ulcers, skin diseases, and oral diseases $[56,64,65]$.

In addition, GA (1) may have a therapeutic effect on allergic rhinitis, partly by modulation of the $\mathrm{Th} 1 / \mathrm{Th} 2$ balance through suppression of OX40 and by increasing the activity of regulatory T cells [66].

\section{Solubilization Characteristics}

In nature, saponins are distributed in 90 plant families from 500 genera [67]. Some of them have the potential to be used as natural surfactants because they contain the nonpolar sapogenin and water-soluble sidechain [68]. Glycyrrhiza is the most frequently used TCM in TCM formulae, with the function of harmonizing all kinds of TCMs. Research on the chemistry, pharmacological effects, clinical applications et al. of glycyrrhiza has been very extensive in recent decades. Besides, the saponins from glycyrrhiza have also significant solubilizing effects [69]. Interestingly, the solubilization characteristics of glycyrrhiza and saponins from glycyrrhiza were studied extensively over recent years. This part of review will deal with the solubilization characteristics, influences, and mechanisms regarding glycyrrhiza and triterpene saponins from glycyrrhiza (Table 3).

\subsection{Solubilization Characteristics of Glycyrrhiza}

Shi et al. [70] reported that glycyrrhiza has solubilization effects in TCM formulae, including sijunzi decoction, huangqi dazao decoction, and baishao gancao decoction, further explaining that the solubilizing components in glycyrrhiza are triterpene saponins. Meng et al. [71] studied and analyzed the decoctions of ephedra and glycyrrhiza, demonstrating that, compared to that of a single decoction, the contents of GL (1), ephedrine (including pseudoephedrine), and methephedrine (including methylpseudoephedrine) in the combined decoction of ephedra and glycyrrhiza were increased by $13.50 \%, 14.52 \%$, and $64.0 \%$, respectively. Nie et al. [72] demonstrated that after administration of a combined decoction of epimedium and glycyrrhiza, the contents of some chemical constituents, such as icariin in epimedium, were increased. Han et al. [73] reported that when extracted with $30 \%$ ethanol (v:v) with a 1:1 ratio of glycyrrhiza to curcuma longa, the extractive rate of curcumin doubled. At the same time, other studies also found that glycyrrhiza increased the contents of active ingredients in codonopsis, poria, atractylodes [74], Baphicacanthus cusia [75], Paeoniae Radix Alba [76], Isatidis Radix [77], and Scutellaria baicalensis [78].

Glycyrrhiza plays a significant role in solubilizing insoluble components, improving the bioavailability of active components and enhancing efficacy, reducing toxicity, and improving taste $[79,80]$. It should be noted that not all glycyrrhiza compounds in TCM formulae have surface activity, because solubilization is also affected by some crude drugs, such as Schisandra chinensis [70]. As for the mechanism of solubilization, most researchers demonstrated that the saponins of glycyrrhiza significantly reduced surface tension to play a solubilizing role, and further agreed that GL (1) is the main surfactant in glycyrrhiza $[73-75,78,81,82]$. 
Table 3. Summary on solubilization of glycyrrhiza and GL (1).

\begin{tabular}{|c|c|c|c|c|c|}
\hline No. & Name & $\begin{array}{c}\text { TCM Formulae/TCM/ } \\
\text { Component }\end{array}$ & Characteristics & Major Findings & References \\
\hline 1 & \multirow{6}{*}{ glycyrrhiza } & $\begin{array}{l}\text { sijunzi decoction, } \\
\text { huangqi dazao } \\
\text { decoction, baishao } \\
\text { gancao decoction }\end{array}$ & $\begin{array}{c}\text { Glycyrrhiza has } \\
\text { solubilization effects in } \\
\text { three traditional } \\
\text { Chinese medicine } \\
\text { (TCM) formulae }\end{array}$ & $\begin{array}{l}\text { The solubilizing } \\
\text { components in } \\
\text { glycyrrhiza are } \\
\text { triterpene saponins }\end{array}$ & {$[70]$} \\
\hline 2 & & ephedra & $\begin{array}{l}\text { The contents of GL (1), } \\
\text { ephedrine, and } \\
\text { methephedrine et al. } \\
\text { all increase }\end{array}$ & - & {$[71]$} \\
\hline 3 & & epimedium & $\begin{array}{l}\text { Icariin in epimedium } \\
\text { increases }\end{array}$ & - & [72] \\
\hline 4 & & curcuma longa & $\begin{array}{l}\text { The extractive rate of } \\
\text { curcumin double }\end{array}$ & $\begin{array}{l}\text { GL (1) is the main } \\
\text { surfactant }\end{array}$ & [73] \\
\hline 5 & & $\begin{array}{l}\text { codonopsis, poria, } \\
\text { atractylodes, } \\
\text { Baphicacanthus cusia, } \\
\text { Paeoniae Radix Alba, } \\
\text { Isatidis Radix, and } \\
\text { Scutellaria baicalensis }\end{array}$ & $\begin{array}{l}\text { Glycyrrhiza can } \\
\text { increase the contents of } \\
\text { active ingredients in } \\
\text { these TCM }\end{array}$ & $\begin{array}{l}\text { GL (1) is the main } \\
\text { surfactant }\end{array}$ & [74-78] \\
\hline 6 & & Schisandra chinensis & $\begin{array}{c}\text { No solubilization } \\
\text { effects }\end{array}$ & $\begin{array}{l}\text { One of the possible } \\
\text { factors affecting the } \\
\text { solubilization is some } \\
\text { other crude drugs }\end{array}$ & [70] \\
\hline 7 & \multirow{6}{*}{ GL (1) } & saikosaponin-a & $\begin{array}{l}\text { The contents of } \\
\text { saikosaponin-a } \\
\text { increase }\end{array}$ & $\begin{array}{l}\text { Solubilizing effect is } \\
\text { due to GL (1) }\end{array}$ & [83] \\
\hline 8 & & Ben Lamge granules & $\begin{array}{l}\text { The solubility of Ben } \\
\text { Lamge granules } \\
\text { increases }\end{array}$ & $\begin{array}{l}\text { 1. The surface tension } \\
\text { of GL (1) decreases; } \\
\text { 2. GL (1) exists in } \\
\text { micelles in aqueous } \\
\text { solution. }\end{array}$ & [82] \\
\hline 9 & & baicalin & $\begin{array}{c}\text { The dissolution rate of } \\
\text { baicalin increases }\end{array}$ & $\cos 2 \cos 20$ & [84] \\
\hline 10 & & pueraria & $\begin{array}{l}\text { The solubility of } \\
\text { pueraria increases }\end{array}$ & $\begin{array}{l}\text { Another possible factor } \\
\text { affecting the } \\
\text { solubilization is the } \mathrm{pH} \\
\text { value of the solution }\end{array}$ & [85] \\
\hline 11 & & pachymic acid & $\begin{array}{l}\text { Increase the solubility } \\
\text { of pachymic acid }\end{array}$ & $\begin{array}{l}\text { Improve the } \\
\text { bioavailability of } \\
\text { pachymic acid }\end{array}$ & [69] \\
\hline 12 & & $\begin{array}{l}\text { Puerarin-glycyrrhizic } \\
\text { acid dispersible tablets }\end{array}$ & $\begin{array}{l}\text { Improve the } \\
\text { dissolution of puerarin }\end{array}$ & $\begin{array}{l}\text { GL (1) possesses } \\
\text { solubilization effect }\end{array}$ & [86] \\
\hline
\end{tabular}

\subsection{Solubilization Characteristics of GL (1)}

Sasaki et al. [83] found that the water solubility of saikosaponin-a, the active principle of Bupleurum root, is increased in the presence of water extract or the saponin fraction of glycyrrhiza and that this solubilizing effect is due to GL (1). Du [82] demonstrated that glycyrrhiza exhibits solubilization on Ben Lamge granules, thereby proving that GL (1) possesses solubilization activity. In detail, the solubility of Ben Lamge granules increases with the addition of GL (1), whereas the surface tension of GL (1) decreases. Experimental results also indicated that GL (1) exists in micelles in aqueous solution, where the critical micelle concentration (CMC) is $1.188 \mathrm{mg} / \mathrm{mL}$. Lu et al. [84] showed that GL (1) exhibits certain solubilization on baicalin, and the dissolution rate of baicalin increases gradually as the concentration of GL (1) increases. The optimal CMC of GL (1) is $0.22 \mathrm{mg} / \mathrm{mL}$ regarding compatibility between Scutellaria baicalensis and glycyrrhiza, at which time the solubilization of GL (1) is at its highest. Yang et al. [85] reported that when the ratio of pueraria and glycyrrhiza was 5:3, the dissolution of puerarin reached its maximum and the CMC of GL (1) was $0.18 \mathrm{mg} / \mathrm{mL}$, which was affected by the structure of the drug and the $\mathrm{pH}$ value of the solution. Cai et al. [69] demonstrated that GL (1) 
increased the solubility of pachymic acid in an aqueous solution, thereby improving the bioavailability of pachymic acid. Liu et al. [86] demonstrated that puerarin-glycyrrhizic acid dispersible tablets could improve the dissolution of puerarin in vitro due to the solubilization effect of GL (1).

GL (1) was reported to possess amphiphilic components consisting of one triterpenoid aglycone molecule and two glycosyl groups. With its inward hydrophobic group (triterpenoid aglycone) and outward hydrophilic group (two glucuronic acids), GL (1) spherical micelles can form in aqueous solution to increase the solubility of hydrophobic drugs. Petrova et al. [87] showed that NMR chemical shifts of the protons of the GL (1) glucuronic moiety were sensitive to solution $\mathrm{pH}$ and not sensitive to GL (1) concentration changes during GL (1) aggregation. At the same time, the protons of the triterpene moiety were shown to be sensitive to the nearest environment, and micelles formed via hydrophobic interaction between the triterpene moieties of GL (1).

GL (1) has potential applications as a biosurfactant in various fields [88]. In recent years, GL (1) was trialed for use as a "vehicle for drug delivery", showing great potential in this field [89-94]. The solubilization effect of GL (1) is also widely used in the food industry $[9,95]$.

\section{Conclusions}

This review provides an up-to-date summary concerning the phytochemistry and pharmacology of glycyrrhiza. Three species of the genus Glycyrrhiza-G. uralensis, G. glabra, and G. inflata-are considered to have a shared botanical origin of Glycyrrhizae Radix et Rhizoma. By the end of 2020, 77 triterpene saponins were discovered and identified from these plants. Previous phytochemical investigations revealed that triterpene saponins are one of the major constituents contributing either directly or indirectly to the biological effects of glycyrrhiza. Over recent decades, total saponins or saponin monomers from glycyrrhiza were found to possess various biological activities, such as hepatoprotective, anti-inflammatory, antimicrobial, antiviral, antitumor, antioxidant, and neuraminidase-inhibitory activities. Currently, these pharmacological studies on glycyrrhiza are limited to bioassays of only a few saponin monomers. Hence, further studies are needed to investigate the biological activities of more triterpene saponins via in vitro/vivo models. In addition, the phytochemistry of glycyrrhiza requires further study, with new compounds or degradation products possibly showing new pharmacological activities.

Another aim of this review was to summarize the solubilization characteristics, influences, and mechanisms regarding triterpene saponins from glycyrrhiza. Glycyrrhiza is widely used in TCM formulae and plays an important role in solubilizing insoluble components, thereby improving the bioavailability of active components, enhancing efficacy, and reducing toxicity, as well as demonstrating various pharmacological effects. The solubilization of glycyrrhiza with ephedra, epimedium, curcuma longa, codonopsis, poria, atractylode, Baphicacanthus cusia, Paeoniae Radix Alba, Isatidis Radix, and Scutellaria baicalensis was previously explored and the possible factors affecting the solubilization of glycyrrhiza were discussed, including some crude drugs and the $\mathrm{pH}$ of decoctions. Therefore, not all glycyrrhiza in a TCM formula possess solubilization activity. The solubilization of GL (1), the main solubilizing component from glycyrrhiza, with multiple active components from some other TCMs was also explored. In the discussion of solubilization mechanisms, the triterpene saponins represented by GL (1) from glycyrrhiza were shown to characteristically form micelles due to their amphiphilicity, thereby showing solubilization ability. The optimal CMC of micelle formation is different when GL (1) is combined with different TCMs or active ingredients. The $\mathrm{pH}$ of the solution was also shown to be critical to the formation of micelles. This review provides guidance regarding the better understanding of TCM compatibility and a theoretical basis for the further development and utilization of glycyrrhiza.

Author Contributions: Data curation, F.L. and B.L.; Figures, F.L. and Z.X.; Investigation, F.L.; B.L.; T.L.; Q.W.; Z.X.; Y.G. and W.L.; Methodology, F.L.; B.L.; P.W. and H.L.; Project administration, H.L.; Supervision, H.L.; Writing-original draft, F.L.; B.L.; T.L.; Q.W.; Z.X.; Writing-review and editing, F.L.; B.L.; P.W. and T.M.; Funding Acquisition, F.L. All authors have read and agreed to the published version of the manuscript. 
Funding: This research was funded by the National Natural Science Foundation of China (No. 81903816), the Fundamental Research Funds for the Central Universities (2019-JYB-JS-018, 2020-JYB-ZDGG-044, BUCM-2019-JCRC002, 2020-JYB-YJ-007, 2019-JYB-TD005 and BUCM-2018-2020, China), Beijing Key Laboratory for Basic and Development Research on Chinese Medicine (Beijing, 100102).

Conflicts of Interest: The authors declare no conflict of interest.

\section{References}

1. Editorial Committee of Flora of China. Flora of China; Science Press: Beijing, China, 2010.

2. Li, N.; Zhou, T.; Wu, F.; Wang, R.; Zhao, Q.; Zhang, J.Q.; Yang, B.C.; Ma, B.L. Pharmacokinetic mechanisms underlying the detoxification effect of Glycyrrhizae Radix et Rhizoma (Gancao): Drug metabolizing enzymes, transporters, and beyond. Expert Opin. Drug Metab. Toxicol. 2019, 15, 167-177. [CrossRef] [PubMed]

3. Li, X.J.Y.; Sun, R.; Liu, R.P. Natural products in licorice for the therapy of liver diseases: Progress and future opportunities. Pharm. Res. 2019, 144, 210-226. [CrossRef] [PubMed]

4. Guo, J.M.; Shang, E.X.; Zhao, J.L.; Fan, X.S.; Duan, J.A.; Qian, D.W.; Tao, W.W.; Tang, Y.P. Data mining and frequency analysis for licorice as a "Two-Face" herb in Chinese Formulae based on Chinese Formulae Database. Phytomedicine 2014, 21, 1281-1286. [CrossRef] [PubMed]

5. Pastorino, G.; Cornara, L.; Soares, S.; Rodrigues, F.; Oliveira, M. Liquorice (Glycyrrhiza glabra): A phytochemical and pharmacological review. Phytother. Res. 2018, 32, 2323-2339. [CrossRef] [PubMed]

6. Hayashi, H.; Sudo, H. Economic importance of licorice. Plant Biotechnol. 2009, 26, 101-104. [CrossRef]

7. Gabriele, D.; Curcio, S.; Cindio, B. Optimal design of single-screw extruder for liquorice candy production: A rheology based approach. J. Food Eng. 2001, 48, 33-44. [CrossRef]

8. Güçlü-Ustündağ, O.; Mazza, G. Saponins: Properties, applications and processing. Crit. Rev. Food Sci. 2007, 47, 231-258. [CrossRef]

9. Isbrucker, R.A.; Burdock, G.A. Risk and safety assessment on the consumption of Licorice root (Glycyrrhiza sp.), its extract and powder as a food ingredient, with emphasis on the pharmacology and toxicology of glycyrrhizin. Regul. Toxicol. Pharm. 2006, 46, 167-192. [CrossRef]

10. Wang, C.C.; Chen, L.H.; Xu, C.Q.; Shi, J.J.; Chen, S.Y.; Tan, M.X.; Chen, J.L.; Zou, L.S.; Chen, C.H.; Liu, Z.X.; et al. Comprehensive review for phytochemical, pharmacological, and biosynthesis studies on Glycyrrhiza spp. Am. J. Chin. Med. 2020, 48, 17-45. [CrossRef]

11. Hosseinzadeh, H.; Nassiri-Asl, M. Pharmacological effects of Glycyrrhiza spp. and its bioactive constituents: Update and review. Phytother. Res. 2015, 29, 1868-1886. [CrossRef]

12. Nassiri-Asl, M.; Hosseinzadeh, H. Review of pharmacological effects of Glycyrrhiza sp. and its bioactive compounds. Phytother. Res. 2008, 22, 709-724.

13. El-Saber Batiha, G.; Magdy Beshbishy, A.; El-Mleeh, A.; Abdel-Daim, M.M.; Prasad Devkota, H. Traditional uses, bioactive chemical constituents, and pharmacological and toxicological activities of Glycyrrhiza glabra L. (Fabaceae). Biomolecules 2020, 10, 352. [CrossRef] [PubMed]

14. Rozi, P.; Abuduwaili, A.; Ma, S.J.; Bao, X.W.; Xu, H.Z.X.; Zhu, J.F.; Yadikar, N.; Wang, J.; Yang, X.J.; Yili, A. Isolations, characterizations and bioactivities of polysaccharides from the seeds of three species Glycyrrhiza. Int. J. Biol. Macromol. 2020, 145, 364-371. [CrossRef] [PubMed]

15. Zhao, Q.; Luan, X.; Zheng, M.; Tian, X.H.; Zhao, J.; Zhang, W.D.; Ma, B.L. Synergistic mechanisms of constituents in herbal extracts during intestinal absorption: Focus on natural occurring nanoparticles. Pharmaceutics 2020, 12, 128. [CrossRef] [PubMed]

16. Zhang, R.Y.; Zhang, J.H.; Wang, M.T. Studies on the saponins from the root of Glycyrrhiza uralensis Fisch. Acta Pharm. Sin. 1986, 21, 510-515.

17. Amagaya, S.; Sugishita, E.; Ogihara, Y.; Ogawa, S.; Okada, K.; Aizawa, T. Comparative studies of the stereoisomers of glycyrrhetinic acid on anti-inflammatory activities. J. Pharm. 1984, 7, 923-928. [CrossRef]

18. Kitagawa, I.; Hori, K.; Sakagami, M.; Zhou, J.L.; Yoshikawa, M. Saponin and sapogenol. XLVIII. On the constituents of the roots of Glycyrrhiza uralensis Fischer from northeastern China. (2). Licorice-saponins D3, E2, F3, G2, H2, J2, and K2. Chem. Pharm. Bull. 1993, 41, 1337-1345. [CrossRef]

19. Baltina, L.A.; Kunert, O.; Fatykhov, A.A.; Kondratenko, R.M.; Spirikhin, L.V.; Baltina, L.A., Jr.; Galin, F.Z.; Tolstikov, G.A.; Haslinger, E. High-resolution ${ }^{1} \mathrm{H}$ and ${ }^{13} \mathrm{C}$ NMR of glycyrrhizic acid and its esters. Chem. Nat. Comp. 2005, 41, 432-435. [CrossRef] 
20. Zheng, Y.F.; Wei, J.H.; Fang, S.Q.; Tang, Y.P.; Cheng, H.B.; Wang, T.L.; Li, C.Y.; Peng, G.P. Hepatoprotective triterpene saponins from the roots of Glycyrrhiza inflate. Molecules 2015, 20, 6273-6283. [CrossRef]

21. Bai, M.; Yao, G.D.; Ren, Q.; Li, Q.; Liu, Q.B.; Zhang, Y.; Wang, X.B.; Huang, X.X.; Song, S.J. Triterpenoid saponins and flavonoids from licorice residues with anti-inflammatory activity. Ind. Crop. Prod. 2018, 125, 50-58. [CrossRef]

22. Kitagawa, I.; Zhou, J.L.; Sakagami, M.; Taniyama, T.; Yoshikawa, M. Licorice-saponins A3, B2, C2, D3, and E2, five new oleanene-type triterpene oligoglycosides from Chinese Glycyrrhizae Radix. Chem. Pharm. Bull. 1988, 36, 3710-3713. [CrossRef]

23. Schmid, C.; Dawid, C.; Peters, V.; Hofmann, T. Saponins from European licorice roots (Glycyrrhiza glabra). J. Nat. Prod. 2018, 81, 1734-1744. [CrossRef] [PubMed]

24. Kitagawa, I.; Zhou, J.L.; Sakagami, M.; Uchida, E.; Yoshikawa, M. Licorice-saponins F3, G2, H2, J2, and K2, five new oleanene-triterpene oligoglycosides from the root of Glycyrrhiza uralensis. Chem. Pharm. Bull. 1991, 39, 244-246. [CrossRef]

25. Kitagawa, I.; Hori, K.; Uchida, E.; Chen, W.Z.; Yoshikawa, M.; Ren, J.L. Saponin and sapogenol. L. On the constituents of the roots of Glycyrrhiza uralensis Fischer from Xinjiang, China. Chemical structures of licorice-saponin L3 and isoliquiritin apioside. Chem. Pharm. Bull. 1993, 41, 1567-1572. [CrossRef] [PubMed]

26. Kitagawa, I.; Sakagami, M.; Hashiuchi, F.; Zhou, J.L.; Yoshikawa, M.; Ren, J.L. Apioglycyrrhizin and araboglycyrrhizin, two new sweet oleanene-type triterpene oligoglycosides from the root of Glycyrrhiza inflata. Chem. Pharm. Bull. 1989, 37, 551-553. [CrossRef]

27. Song, W.; Si, L.L.; Ji, S.; Wang, H.; Fang, X.M.; Yu, L.Y.; Li, R.Y.; Liang, L.N.; Zhou, D.M.; Ye, M. Uralsaponins $\mathrm{M}-\mathrm{Y}$, Antiviral triterpenoid saponins from the roots of Glycyrrhiza uralensis. J. Nat. Prod. 2014, 77, 1632-1643. [CrossRef]

28. Li-Yang, J.W.; Nakajima, J.; Kimura, N.; Saito, K.; Seo, S. Oleanane-type triterpene glycosides from Glycyrrhiza uralensis. Nat. Prod. Commun. 2007, 2, 243-248. [CrossRef]

29. Zheng, Y.F.; Qi, L.W.; Cui, X.B.; Peng, G.P.; Peng, Y.B.; Ren, M.T.; Cheng, X.L.; Li, P. Oleanane-type triterpene glucuronides from the roots of Glycyrrhiza uralensis Fischer. Planta Med. 2010, 76, 1457-1463. [CrossRef]

30. Xu, J.F.; Luo, J.G.; Kong, L.Y. Simultaneous separation of triterpenoid saponins and flavonoid glycosides from the roots of Glycyrrhiza uralensis Fisch by pH-zone-refining counter-current chromatography. J. Sep. Sci. 2013, 36, 3295-3301. [CrossRef]

31. Wei, J.H.; Zheng, Y.F.; Li, C.Y.; Tang, Y.P.; Peng, G.P. Bioactive constituents of oleanane-type triterpene saponins from the roots of Glycyrrhiza glabra. J. Asian Nat. Prod. Res. 2014, 16, 1044-1053. [CrossRef]

32. Liu, Y.Y.; Yang, Y.N.; Feng, Z.M.; Jiang, J.S.; Zhang, P.C. Eight new triterpenoid saponins with antioxidant activity from the roots of Glycyrrhiza uralensis Fisch. Fitoterapia 2019, 133, 186-192. [CrossRef] [PubMed]

33. Zhang, H.; Wang, S.S.; Li, W.; Wang, Y.Q.; Xue, X.Y.; Liang, X.M. A New oleanane-type triterpene glycoside in Glycyrrhiza uralensis. World Sci. Technol. 2009, 11, 253-256.

34. Zhu, X.M.; Di, Y.T.; Peng, S.L.; Wang, M.K.; Ding, L.S. Chemical constituents from root of Glycyrrhiza uralensis. Chin. Tradit. Herb. Drugs 2003, 34, 198-201.

35. Leng, J.; Zhu, Y.X.; Chen, L.L.; Wang, S.F. Two new triterpenoid saponins from roots and rhizomes of Glycyrrhiza uralensis. Chin. Tradit. Herb. Drugs 2015, 46, 1576-1582.

36. Shou, Q.Y.; Jiao, P.; Hong, M.; Jia, Q.; Prakash, I.; Hong, S.; Wang, B.; Bechman, A.; Ma, G. Triterpenoid saponins from the roots of Glycyrrhiza glabra. Nat. Prod. Commun. 2019, 14, 19-22. [CrossRef]

37. Zapesochnaya, G.G.; Zvonkova, E.N.; Kurkin, V.A.; Kazakova, E.V.; Pervykh, L.N.; Sheichenko, B.I.; Bykov, V.A. Some properties of glycyrrhizic acid. Chem. Nat. Compd. 1994, 30, 720-726. [CrossRef]

38. Wu, X.M.; Lu, J.; Ru, R.P. Study of epimeric 18-glycyrrhizic acid. Chin. Pharm. J. 1993, 4, 215-218.

39. Nakamura, T.; Fujii, T.; Ichihara, A. Enzyme leakage dueto change of membrane permeability of primary cultured rat hepatocytes treated with various hepatotoxins and its prevention by glycyrrhizin. Cell Biol. Toxicol. 1985, 1, 285-295. [CrossRef]

40. Sato, H.; Goto, W.; Yamamura, J.; Kurokawa, M.; Kageyama, S.; Takahara, T.; Akiharu Watanabe, A.; Shiraki, K. Therapeutic basis of glycyrrhizin on chronichepatitis B. Antivir. Res. 1996, 30, 171-177. [CrossRef]

41. Tsuruoka, N.; Abe, K.; Wake, K.; Takata, M.; Hatta, A.; Sato, T.; Inoue, H. Hepatic protection by glycyrrhizin and inhibition of iNOS expression in concanavalin A-induced liver injury in mice. Inflamm. Res. 2009, 58, 593-599. [CrossRef] 
42. Lee, C.H.; Park, S.W.; Kim, Y.S.; Kang, S.S.; Kim, J.A.; Lee, S.H.; Lee, S.M. Protective mechanism of glycyrrhizin on acute liver injury induced by carbon tetrachloride in mice. Biol. Pharm. Bull. 2007, 30, 1898-1904. [CrossRef] [PubMed]

43. Lin, G.; Nnane, I.P.; Cheng, T.Y. The effects of pretreatment with glycyrrhizin and glycyrrhetinic acid on the retrorsine-induced hepatotoxicity in rats. Toxicon 1999, 37, 1259-1270. [CrossRef]

44. Nagai, T.; Egashira, T.; Kudo, Y.; Yamanaka, Y.; Shimada, T. Attenuation of dysfunction in the ischemia reperfused liver by glycyrrhizin. Jpn. J. Pharm. 1992, 58, 209-218. [CrossRef] [PubMed]

45. Orazizadeh, M.; Fakhredini, F.; Mansouri, E.; Khorsandi, L. Effect of glycyrrhizic acid on titanium dioxide nanoparticles-induced hepatotoxicity in rats. Chem. Biol. Interact. 2014, 220, 214-221. [CrossRef] [PubMed]

46. Li, X.H.; Qi, Y.; Cai, R.L.; Liu, B.; Song, Y.; Xie, C. Studies on the anti-inflammatory mechanism of total saponins of Radix Glycyrrhiza in vitro. Chin. J. Exp. Tradit. Med. Formulae 2010, 16, 110-113.

47. Wang, X.R.; Hao, H.G.; Chu, L. Glycyrrhizin inhibits LPS-induced inflammatory mediator production in endometrial epithelial cells. Microb. Pathog. 2017, 109, 110-113. [CrossRef]

48. Akamatsu, H.; Komura, J.; Asada, Y.; Niwa, Y. Mechanism of anti-inflammatory action of glycyrrhizin: Effects on neutrophil functions including reactive oxygen species generation. Planta Med. 1991, 57, 119-121. [CrossRef]

49. Li, Y.; Sun, F.B.; Jing, Z.H.; Wang, X.H.; Hua, X.M.; Wan, L. Glycyrrhizic acid exerts anti-inflammatory effect to improve cerebral vasospasm secondary to subarachnoid hemorrhage in a rat model. Neurol. Res. 2017, 39, 727-732. [CrossRef]

50. Pang, H.G.; Huang, T.Q.; Song, J.N.; Li, D.D.; Zhao, Y.L.; Ma, X.D. Inhibiting HMGB1 with glycyrrhizic acid protects brain injury after DAI via its anti-inflammatory effect. Mediat. Inflamm. 2016, 3, 4569521-4569529. [CrossRef]

51. Moghimipour, E.; Ameri, A.; Handali, S.; Ramezani, Z.; Azemi, M.E.; Sadeghi-Nejad, B. In-vitro evaluation of antibacterial activity of Glycyrrhiza glabra and Acanthopyllum squarrusom total saponins. Res. J. Pharm. Biol. Chem. Sci. 2015, 6, 764-768.

52. Wang, L.Q.; Yang, R.; Yuan, B.C.; Liu, Y.; Liu, C.S. The antiviral and antimicrobial activities of licorice, a widely-used Chinese herb. Acta Pharm. Sin. B 2015, 5, 310-315. [CrossRef] [PubMed]

53. Baba, M.; Shigeta, S. Antiviral activity of glycyrrhizin against varicella-zoster virus in vitro. Antivir. Res. 1987, 7, 99-107. [CrossRef]

54. Hoever, G.; Baltina, L.; Michaelis, M.; Kondratenko, R.; Baltina, L.; Tolstikov, G.A.; Doerr, H.W.; Cinatl, J. Antiviral activity of glycyrrhizic acid derivatives against SARS-coronavirus. J. Med. Chem. 2005, 48, 1256-1259. [CrossRef]

55. Wolkerstorfer, A.; Kurz, H.; Bachhofner, N.; Szolar, O.H. Glycyrrhizin inhibits influenza A virus uptake into the cell. Antivir. Res. 2009, 83, 171-178. [CrossRef] [PubMed]

56. Sun, Z.G.; Zhao, T.T.; Lu, N.; Yang, Y.A.; Zhu, H.L. Research progress of glycyrrhizic acid on antiviral activity. Mini Rev. Med. Chem. 2019, 19, 826-832. [CrossRef]

57. Murck, H. Symptomatic protective action of Glycyrrhizin (Licorice) in COVID-19 Infection? Front. Immunol. 2020, 11, 1239. [CrossRef]

58. Deng, Q.P.; Wang, M.J.; Zeng, X.; Chen, G.G.; Huang, R.Y. Effects of glycyrrhizin in a mouse model of lung adenocarcinoma. Cell Physiol. Biochem. 2017, 41, 1383-1392. [CrossRef]

59. Chan, H.T.; Chan, C.; Ho, J.W. Inhibition of glycyrrhizic acid on aflatoxin $B_{1}$-induced cytotoxicity in hepatoma cells. Toxicology 2003, 188, 211-217. [CrossRef]

60. Bonafé, G.A.; Dos Santos, J.S.; Ziegler, J.V.; Umezawa, K.; Ribeiro, M.L.; Rocha, T.; Ortega, M.M. Growth Inhibitory Effects of dipotassium Glycyrrhizinate in glioblastoma cell lines by targeting MicroRNAs through the NF-кB signaling pathway. Front. Cell. Neurosci. 2019, 13, 216-230. [CrossRef]

61. Akman, T.; Guven, M.; Aras, A.B.; Ozkan, A.; Sen, H.M.; Okuyucu, A.; Kalkan, Y.; Sehitoglu, I.; Silan, C.; Cosar, M. The neuroprotective effect of glycyrrhizic acid on an experimental model of focal cerebral ischemia in rats. Inflammation 2015, 38, 1-8. [CrossRef]

62. Ojha, S.; Javed, H.; Azimullah, S.; Abul Khair, S.B.; Haque, M.E. Glycyrrhizic acid attenuates neuroinflammation and oxidative stress in rotenone model of parkinson's disease. Neurotox. Res. 2015, 29, 1-13. [CrossRef] [PubMed]

63. Ming, L.J.; Yin, A.C. Therapeutic effects of glycyrrhizic acid. Nat. Prod. Commun. 2013, 8, 415-418. [CrossRef] [PubMed] 
64. Doll, R.; Hill, I.D.; Hutton, C.; Underwood, D.J. Clinical trial of a triterpenoid liquorice compound in gastric and duodenal ulcers. Lancet 1962, 2, 793-796. [CrossRef]

65. Sidhu, P.; Shankargouda, S.; Rath, A.; Hesarghatta Ramamurthy, P.; Fernandes, B.; Kumar Singh, A. Therapeutic benefits of liquorice in dentistry. J. Ayurveda Integr. Med. 2020, 11, 82-88. [CrossRef]

66. Fouladi, S.; Masjedi, M.; Ghasemi, R.; Hakemi, M.G.; Eskandari, N. The in vitro impact of glycyrrhizic acid on CD4+ T lymphocytes through OX40 receptor in the patients with allergic rhinitis. Inflammation 2018, 41, 1690-1701. [CrossRef] [PubMed]

67. Chandel, R.S.; Rastogi, R.P. Triterpenoid saponins and sapogenins: 1973-1978. Phytochemistry 1980, 19, 1889-1908. [CrossRef]

68. Ralla, T.; Salminen, H.; Braun, K.; Edelmann, M.; Dawid, C.; Hofmann, T.; Weiss, J. Investigations into the structure-function relationship of plant-based surfactant glycyrrhizin: Interfacial behavior \& emulsion formation. LWT 2019, 120, 108910.

69. Cai, S.Y.; Lv, S.W.; Wang, Y.H.; Guo, Y.Y.; Li, Y.J. Solubility and apparent oil/ water partition coefficient of glycyrrhizin and pachymic acid. Inf. Tradit. Chin. Med. 2012, 29, 118-121.

70. Shi, K.L.; Yang, L.L.; Tan, S.F. Compatibility and solubilization of Glycyrrhiza uralensis. China J. Chin. Mater. Med. 1990, 15, 32-33.

71. Meng, X.Y.; Pi, Z.F.; Song, F.R.; Liu, Z.Q.; Liu, S.Y. Changes in the effective compounds and the anti-inflammatory activity before and after the decoction of Ephedra and Liquorite. Chin. J. Appl. Chem. 2009, 26, 801-806.

72. Nie, J.; Chen, S.J.; Gao, G.; Yang, Q.Q.; Han, J.J.; Wang, Y.J.; Li, Q. Effect of Epimedium brevicornu Maxim and Glycyrrhiza compatibility application on the content of icariin. Northwest Pharm. J. 2009, 34, 295-297.

73. Han, G.; Yan, H.M.; Li, L.L.; Zhang, W.G.; Jin, G.C. Effects of Radix Glycyrrhizae uralensis on extractive rate of curcumin from curcuma longa. West China J. Pharm. Sci. 2007, 22, 652-653.

74. Li, M. A Preliminary Study on the Solubilization of Glycyrrhizae Radix et Rhizoma. Sci. Brief. 1984, 2, 37. Available online: https://kns.cnki.net/KCMS/detail/detail.aspx?dbcode=CJFQ\&dbname=CJFD7984\&filename= ZCYA198402028\&uid=WEEvREcwSIJHSIdSdmVqM1BLUWdMQ2w4MnNOOXZGYVc0Rmc2SGZ5M0ZZaz0 (accessed on 25 August 2020).

75. Chen, L.; Xu, R.C.; Zou, W.Q.; Yang, M. Investigation of solubilization effect from compatibility of Glycyrrhiza uralensis-Baphicacanthus cusia. Chin. J. Exp. Tradit. Med. Formulae 2012, 18, 17-19.

76. Li, Y.; Yang, Y.Y.; Zhang, Z.Q.; Xie, J.L.; Wang, M. Principle of active component dissolution in extract of different compatibility proportions of Paeoniae Radix Alba and Glycyrrhizae Radix et Rhizoma. Chin. Tradit. Herb. Drugs. 2013, 44, 291-295.

77. Du, W. Study on the solubility of Glycyrrhizae Radix et Rhizoma. Hunan Guid. J. Tcm P 1996, 12, 32-33. Available online: https://kns.cnki.net/ KCMS/detail/detail.aspx?dbcode=CJFQ\&dbname=CJFD9697\&filename=HNZB606.023\&uid= WEEvREcwSIJHSIdSdmVqM1BLUWdMQ2w4MnNOOXZGYVc0Rmc2SGZ5M0ZZaz0=\$9A4hF_ YAuvQ5obgVAqNKPCYcEjKensW4IQMovwHtwkF4VYPoHbKxJw!!\&v=MDYwMjR6aEFVNGpoNE9 YNIRySDAzZWJDVVJiS2RZZWRyRXIIaFd3PT1MU1BSYkxXNEdNL01yWXdxRjU0T2ZnZzU= (accessed on 25 August 2020).

78. Lv, Z.Y.; Shan, C.; Yang, Y.W.; Gu, X.M.; Chen, J.; Wei, Y. Effect of baicalin in licorice by different compatibility proportion on the dissolution of baicalin. Asia-Pac. Tradit. Med. 2019, 15, 67-69. Available online: https://kns.cnki.net/KCMS/detail/detail.aspx?dbcode=CJFQ\&dbname=CJFDLAST2019\&filename= YTCT201910020\&uid=WEEvREcwSlJHSldSdmVqM1BLUWdMQ2w4MnNOOXZGYVc0Rmc2SGZ5M0ZZaz0= \$9A4hF_YAuvQ5obgVAqNKPCYcEjKensW4IQMovwHtwkF4VYPoHbKxJw!!\&v=MTQ2MjJDVVI3cWZiK1 JwRnkzZ1VMckpQRG5JZXJHNEg5ak5yNDIIWklSOGVYMUx1eFlTN0RoMVQzcVRyV00xRnI= (accessed on 30 October 2019).

79. Lv, S.W.; Duan, J.X.; Guo, Y.Y.; Sun, S.; Kuang, H.X. Research progress on the mechanism of formula compatibility of Glycyrrhizae Radix et Rhizoma. Chin. Tradit. Pat. Med. 2015, 37, 2022-2025.

80. Wang, X.Y.; Zhang, H.; Chen, L.L.; Shan, L.H.; Fan, G.W.; Gao, X.M. Liquorice, a unique "guide drug" of traditional Chinese medicine: A review of its role in drug interactions. J. Ethnopharmacol. 2013, 150, 781-790. [CrossRef]

81. Ma, H.Y.; Deng, Y.J.; Ma, Q.; Wang, J.Y.; Xu, R.C. Review of research on Gancao. Pharma. Clin. Chin. Mater. Med. 2018, 1, 59-62. 
82. Du, W. Solubilization of glycyrrhizin on Ben Lamge Granules. Chin. J. Hosp. Pharm. 1997, 17, $314-315$.

83. Sasaki, Y.; Mizutani, K.; Kasai, R.; Tanaka, O. Solubilizing properties of glycyrrhizin and its derivatives: Solubilization of saikosaponin-a, the saponin of Bupleuri Radix. Chem. Pharm. Bull. 1988, 36, 3491-3495. [CrossRef]

84. Lu, B.; Yang, X.; Wang, B.H.; Shi, X.Y.; Wang, Y.; Li, J.; Shao, L.; Yang, B.B.; Li, P. Solubilizing effect of glycyrrhizic acid on baicalin. J. Beijing Univ. Tradit. Chin. Med. 2014, 37, 620-624.

85. Yang, X.; Wang, Y.; Wang, B.H.; Shi, X.Y.; Lu, B.; Shao, L.; Li, P.; Yang, B.B. Research of the solubilization of glycyrrhizic acid to puerarin. Tianjin J. Tradit. Chin. Med. 2015, 32, 304-307.

86. Liu, X.W.; Zhuo, H.Y.; Xu, X.; Li, W.; Zou, L.; Song, Y. Study on puerarin dispersible tablet based on solubilization effect of glycyrrhizic acid. China J. Chin. Mater. Med. 2019, 44, 1350-1356.

87. Petrova, S.S.; Schlotgauer, A.A.; Kruppa, A.I.; Leshina, T.V. Self-association of glycyrrhizic acid. NMR study. Z. Phys. Chem. 2016, 231, 1-17. [CrossRef]

88. Matsuoka, K.; Miyajima, R.; Ishida, Y.; Karasawa, S.; Yoshimura, T. Aggregate formation of glycyrrhizic acid. Colloids Surf. A Phys. Eng. Asp. 2016, 500, 112-117. [CrossRef]

89. Su, X.T.; Wu, L.; Hu, M.M.; Dong, W.X.; Xu, M.; Zhang, P. Glycyrrhizic acid: A promising carrier material for anticancer therapy. Biomed. Pharm. 2017, 95, 670-678. [CrossRef]

90. Polyakov, N.E.; Leshina, T.V. Glycyrrhizic acid as a novel drug delivery vector synergy of drug transport and efficacy. Open Conf. Proc. J. 2011, 2, 64-69. [CrossRef]

91. Shi, L.; Tang, C.; Yin, C. Glycyrrhizin-modified O-carboxymethyl chitosan nanoparticles as drug vehicles targeting hepatocellular carcinoma. Biomaterials 2012, 30, 7594-7604. [CrossRef]

92. Li, Y.; Wang, L.F.; Wang, J.L.; Tu, P.F. Research on preparation process of andrographolide-glycyrrhizic acid polymeric micelles. China J. Chin. Mater. Med. 2018, 43, 79-85.

93. Deng, Y.G.; Lv, X.L.; Zhu, Y.L.; Zhang, S.C.; Liu, S.J.; Zhao, B.X.; Li, G.F. Preparation and anti-hepatic fibrosis activity of evodiamine-glycrrhizic acid micelles using glycyrrhizic acid as the drug carrier. China J. Chin. Mater. Med. 2020. Available online: http://kns.cnki.net/kcms/detail/11.2272.R.20200428.1605.004.html (accessed on 25 August 2020).

94. Yang, F.H.; Liu, X.D.; Liu, S.J.; Liang, Q.Y.; Cai, Y.; Zhang, Y.Q.; Li, G.F. Solubilization effects of glycyrrhizic acid on paclitaxel. Chin. J. Hosp. L Pharm. 2016, 36, 1873-1877.

95. Wan, Z.L.; Sun, Y.G.; Ma, L.L.; Yang, X.Q.; Guo, J.; Yin, S.W. Responsive emulsion gels with tunable properties formed by self-assembled nanofibrils of natural saponin glycyrrhizic acid for oil structuring. J. Agric. Food Chem. 2017, 65, 2394-2405. [CrossRef] [PubMed] 